\title{
Eski Anadolu Türkçesi Dönemine Ait Bir Hikâye: Aksarayli Îsâ: Hikâyet-i Şuhmâ [06 Mil Yz A 6823/2]
}

\section{A Story From Old Anatolian Turkish Period: Aksarayli Îsâ: Hikâyet-i Şuhmâ [06 Mil Yz A 6823/2]}

\author{
Şenol KoRKMAZ \\ İstanbul/Turkey \\ E-mail: senolkorkmaz78@gmail.com
}

\begin{abstract}
Aksaraylı Îsâ lived in the XIV ${ }^{\text {th }}$ century around Konya and Aksaray. It is understood from his works that he received a good education and was familiar with religious sciences. Only four of his works have survived today. If the literature is reviewed, new works may be revealed. The subjects he dealt with are about religion and morality. He aimed to popularize Islam and to explain some simple religious information to the public through his works. In this study, Hikâyet-i Şuhmâ of Aksaraylı Îsâ, which is registered at Ankara National Library 06 Mil Yz A 6823/2, is studied. There is only one known copy of the work. Hikâyet-i Şuhmâ has not been the subject of any scientific studies so far. In this study, the transcribed text, translation and index of the story has been given and various literary and philological studies have been conducted on the work. Thus, it was aimed to introduce the work to the scientific world and also to contribute to the studies on Aksaraylı Îsâ, one of the meddâh poets of the XIV ${ }^{\text {th }}$ century.
\end{abstract}

Key Words: Old Anatolian Turkish, story, masnavi, Islamic religion, Aksaraylı Îsâ. 


\section{Giriş}

Hikâye ya da öykülemeye dayalı eserler insanlık tarihinin en eski ürünlerindendir. İnsanlar tarihin en eski dönemlerinden beri kendileri için önemli olay ve durumları hikâyeler hâlinde sonraki nesillere aktarmışlardır. En eski dönemlerden itibaren yazılı ve sözlü bir kültür geleneğine sahip tüm toplumlarda bir hikâye geleneği vardır (Yağc1 2002: 147). Yazılı veya sözlü olarak her dönemde örnekleri görülen hikâye türü en eski anlatma sanatlarından birisidir (Hikâye 1981: 226). Hikâye kelimesi, bir olayın yazılı veya sözlü olarak anlatılması; bu şekilde anlatılan olay anlamındadır. Edebî olarak ise roman türüne giren anlatı; konusunun kısalığı, özentisizliği ve sadeliği ile romandan ayrılır, şeklinde tanımlanmaktadır (Hikâye 1971: 850). Batılı anlamda hikâye türü, Tanzimat Dönemi'nde (1860-1896) edebiyatımıza girmiştir. Eski dönem edebiyatımızda hikâye kelimesi bir tür adı olmaktan ziyade bir şeyi nakletme veya bir olay anlatma sanatıdır. Küçücük bir eserden binlerce beyitlik bir mesneviye kadar olay anlatımına dayalı her eser eski edebiyatımızda "hikâye" tanımı içerisindedir.

Türk edebiyatında hikâye türü çok köklü bir geleneğe sahiptir. İslamiyet'ten önceki dönemlerde hikâyeler daha çok destanlar şeklinde anlatılır ve sözlü gelenekte yaşardı. Uygurlar Dönemi'nde yazılı olarak da epey hikâye günümüze kadar gelmiştir. Uygurlar zamanında Budizm ve Maniheizm dinlerinin çevresinde güçlü bir yazılı edebiyat oluşmuştur. Bununla birlikte hikâye türü Türklerin Karahanlılar zamanında İslamiyet'i kabul etmesiyle (999) birlikte geniş bir zemine oturmuştur. İslam dininin, Arap ve İran edebiyatlarının da etkisiyle Türk edebiyatında sağlam bir hikâyecilik geleneği oluşmuştur.

Anadolu sahasında Türkçe olarak kaleme alınan hikâyeler XIII. yüzyıldan itibaren görülmektedir. Bu dönemde özellikle Anadolu'daki beylikleri yöneten beylerin Türkçeye ve millî ruha bağlılıkları sayesinde pek çok Türkçe eser yazılmıştır. Beylikler Dönemi'nde Kur'an tercümeleri, peygamber kıssaları, evliya menkıbeleri, nasihatnâmeler, tıbba, baytarlığa, avcılığa, cevherlere, rüya tabirlerine ait çeşitli tercüme ve telif kitaplar; edebî alanda dinî, destanî manzum ve mensur eserler, tasavvufi ve romantik mesneviler, divanlar vb. birçok eser meydana getirilmiştir (Özkan 2009: 74).

Aksaraylı Îsâ da Anadolu sahasında XIV. yüzyılda eserler yazmış bir meddâh şairdir. Aksaraylı Îsâ'dan günümüze gelen eserlerin sayısı şimdiki bilgilerimize göre dörttür. Bu mesnevilerin hepsi İslam dini ile ilgili dinî ve ahlaki eserlerdir. Basit halk ruhuna uygun olarak son derece sade ve akıcı bir halk diliyle kaleme alınan bu eserler köy ve kasabalarda halk meclislerinde okunmuştur. Amaç bu tür eserler yoluyla bazı 
basit bilgileri insanlara anlatmak ve İslam dinini sevdirmektir. Bu tür eserlerde genelde kıssadan hisse verilir. Sıklıkla işlenen ana düşünce bu dünyanın geçici olduğu, ebedî ve kalıcı olanın öte dünya olduğu fikridir.

Bu çalışmada Aksaraylı Îsâ’nın 103 beyitlik kısa bir mesnevisi olan Hikâyet-i Şuhmâ adlı eseri ele alınacaktır. Eserin bilinen tek bir nüshası vardır ve daha önce eser üzerine hiçbir çalışma yapılmamıştır. Çalışmada eser üzerine çeşitli incelemeler yapılarak eserin transkripsiyonlu metni, çevirisi ve dizini verilecektir. Sonuç bölümünde ise elde edilen bilgiler özetlenecektir.

\section{2. İnceleme}

\subsection{Eser ve Eserin Adl}

Eser, Arap harfleriyle yazılmış İslami Dönem Türk edebiyatına ait manzum bir halk hikâyesidir. Hikâye halk için yazılıp söylendiğinden dolayı dili oldukça sade ve akıcı bir halk dilidir. Eserde arkaik ve ağız özelliği taşıyan kelimeler de yer almaktadır. Eser, Eski Anadolu Türkçesi dil özellikleri taşımaktadır. Ne zaman yazıldığı tam olarak belli olmamakla birlikte yazarı Aksaraylı Îsâ'dan hareketle XIV. yüzyılda yazıldı̆̆ı tahmin edilmektedir. Eser, ümmet çağı dönemi edebiyat ürünü olduğu için dinî bir konuda yazılmıştır. Amaç bazı basit dinî bilgileri geniş halk kitlelerine aktarmak ve kıssadan hisse çıkarmaktır.

Eserin adı, Millî Kütüphane 06 Mil Yz A 6823/2 numarada kayıtlı tek yazmasında Destân- 1 Şuhmâ ve Hikâyet-i Şuhmâ olarak iki ayrı şekilde belirtilmiştir. Eski Türk edebiyatında hikâye bir tür adı olarak henüz keskin çizgilerle ayrılmadığı için bu türden pek çok eser için benzer adlar ve farklı terimler kullanılmıştır. Eserin adını günümüz Türkçesine Şuhmẩnın Hikâyesi olarak çevirebiliriz.

\subsection{Eserin Konusu ve İçeriği}

Eser, İslamî dönem Türk edebiyatına ait dinî ve ahlaki konulu manzum bir halk hikâyesidir. Eser mesnevi tarzında yazılmıştır ve 103 beyitten oluşan kısa bir hikâyedir. Hikâyede Hz. Ömer'in oğlu Şuhmâ'nın bir gün meclisten eve giderken bir Yahudi'ye rastlaması ve sonrasında gelişen olaylar anlatılmaktadır. Şuhmâ, hikâyede zina yaptığı için yüz kamçı cezasına çarptırılmış, ceza sonucunda can vermiştir.

Hikâyede daha çok İslam hukuku alanına giren bir konu işlenmiştir. Burada verilmek istenen ana fikri iki açıdan yorumlamak mümkündür: 1. Hz. Ömer’in oğlu da 
olsanız herkes Allah'ın şeriatı (kuralları) karşısında eşittir. Kurallar hiçbir ayrım gözetilmeden herkese eşit bir şekilde uygulanır. 2. Hikâyeyi evrensel açıdan yorumlarsak herkes hukuk karşısında eşittir ve hiç kimsenin kimseden ayrıcalığı yoktur.

Hikâyet-i Şuhmầ'da basit bazı dinî ve ahlaki kurallar hikâyeleştirilerek geniş halk kitlelerine ulaştırılmak istenmiştir. Bu tür hikâyelerde amaç halka İslami konularda basit bazı bilgileri vermek ve kıssadan hisse çıkarmaktır. Beylikler ve Osmanlının kuruluş yıllarında (XIII. ve XV. yüzyıllar) çoğunlukla yazılan ve halk meclislerinde okunan bu tür hikâyelerle aynı zamanda halkta bir dinamizm ve coşku da uyandırılmak istenmiştir. Bu tür hikâyeler basit halk ruhuna uygun olarak son derece basit bir kurgu içinde, sade ve akıcı bir halk diliyle yazılırlar. Bunun sonucu olarak da bu hikâyeler; Türkçenin söz varlığı, deyimler, ağız ve arkaik kelimeler açısından eşsiz bir öneme sahiptirler.

Hikâyeyi ilk okuduğumda bunun hayalî bir hikâye olduğunu düşündüm, ayrıca Hz. Ömer'in Şuhmâ adlı bir çocuğu da yoktu. Bu tür hikâyeler gerçek bir konudan hareketle oluşturulabildiği gibi tamamen hayalî olaylara da dayanabilmektedirler. İbn Hacer el- Askalânînin (M. 1372-1449) el-İsâbe adlı eserindeki bilgiler bu hikâyenin gerçek bir olaydan yola çıkılarak ortaya konulduğunu kanıtlamıştır. İbn Hacer el- Askalânînnin eseri dilimize Sahâbe-i Kirâm Ansiklopedisi, el-İsâbe adıly 5 cilt olarak Naim Erdoğan tarafından 2009 yılında çevrilmiştir. Eserin 3. cildinde 6231 numarada Abdurrahman b. Ömer başlığı altında şu bilgiler verilmiştir:

\footnotetext{
"Abdurrahman b. Ömer b. el-Hattâb b. Nüfeyl el-Kureşî el- Adevî Abdurrahman el-Evsat'tır. Künyesi Ebu Şahme'dir. Büyük kardeşinin adı Birinci Kısım'da geçmişti. İbn Abdilber Ebu Şahme’yi kardeşinin biyografisinde anıp şöyle dedi: 'Amr b. Âs'ın, Mısır'da içki yüzünden dövdüğü kişi odur. Sonra onu Medine'ye götürdü, bu defa da babası onu te'dîb etmek için dövdü, derken hastalandı ve bir ay sonra da öldü.' Bunu Ma'mer, Zührî, Salim babasından böyle tahric etti. Iraklılara gelince, onlar şöyle diyorlar: 'Kendisine kamçı cezası uygulanırken öldü.' Bu yanlıştır. Abdurrezzak bu hikâyeyi gayet uzun olarak, mezkûr senedle Ma'mer'den naklederek tahric etti. Doğru olan da budur. Ömer, Resulullah'tan sonra on üç yıl daha yaşadı. Abdurrahman, babasından bir süre önce öldü. Had (şer’î ceza) ancak âkıl-bâliğ olan kimseye uygulanır. Mısır’a da ancak ya ergenlik çağına ermiş ya da ergenlik çağına yaklaşmış kişi gidebilir. Şu hâlde onun bu bölümden olması apaçık ortaya çıkmıştır." (ibn-i Hacer el-Askalânî III, 2009: 616).
}

Yukardaki alıntıya baktığımız zaman hikâye bir gerçeklik zeminine dayanmaktadır ancak alıntı da zina olayı geçmemektedir. Iraklıların rivayetinde kamçı cezası var ama ne sebeple olduğu belirtilmiyor. O hâlde hikâyenin düzenleyicisi Aksaraylı Îsâ, hikâyeyi farklı bir rivayetten yararlanarak oluşturmuş olmalıdır. Yazarın gerçek bir kaynaktan aldığı olayı, kendi hayal gücü ile birleştirip hikâyeyi oluşturmuş olması da güçlü bir ihtimaldir. 


\title{
2.3. Eserin Kaynağı
}

Eser, Arap-İslam kaynaklı bir halk hikâyesidir. Bu türden bazı hikâyeler Arap veya İran edebiyatından çeviri veya adapte yoluyla gelmektedir. Yani hikâyeye kaynak olan konu Arap ve İran edebiyatında da hikâye şeklinde vardır. Bazı konular ise İslam tarihi, ayet, hadis vb. kaynaklardan yola çıkılarak Türk edebiyatında oluşturulmuştur. Hikâyet-i Şuhmẩnın Arap edebiyatında da hikâye olarak anlatılıp anlatılmadığını bilmiyoruz. Ancak konuya kaynak teşkil eden bilgiler İslam tarihinde bilinmektedir. Aksaraylı Îsâ, bu konuyu İslam tarihi kaynaklarından alıp kendi hayal gücü ile hikâyeleştirmiş olabilir. Bu konuda bilgilerimiz oldukça kısıtlıdır.

Murat Sarıcık, Adalet Timsali Hz. Ömer (r.a.) adlı kitabında bu olayı "Adalet ve Hz. Ömer'in Oğlu" başlığında şöyle değerlendirmiştir:

\begin{abstract}
“Bilindiği gibi Hz. Ömer H. 14 (M. 635) yılında, şarap içen bazı gençlere had cezası (Allah'ın bir suç için açıkça belirttiği ceza) uygulamıştı. Had cezası uygulananlardan biri de oğlu Abdurrahman elAsğar'dı. O 'Ebu Şahme' diye biliniyordu. Olay şöyle gelişmişti: O zamanlar Abdurrahman Mısır eyaletinde bulunuyordu. Bir akşam Abdurrahman ve Ebu Servea Ukbe b. Haris, şarap içtiler ve sarhoş oldular. Abdurrahman'ın ağabeyi Abdullah da o günler Mısır'daydı. Sabah olunca iki genç Mısır Valisi Amr b. As'ın makamına vardılar ve valiye şöyle dediler: 'Biz dün akşam içki içtik, sarhoş olduk, (ceza ver de) bizi temizle.' Abdurrahman aynı itirafı ağabeyi Abdullah'a da yapmış: 'Allah beni şaşırttı. Geçtiğimiz akşam ben ve Ebu Servea şarap içip sarhoş olduk.' demişti. Ağabeyi valinin durumdan haberi olduğunu bilmiyordu, ona şöyle dedi: 'iç̧eri (eve) gir, seni temizleyeyim. O zamanlar içki haddi/seksen sopa vurulan suçluların ayrıca saçları da kesiliyordu. Ağabeyi onun saçlarını kesmek istiyordu. Küçük kardeşi ona ayrıca şunları da söyledi: ‘Ben valiye de (şarap içtiğimi) söyledim.' Derken iki suçlu da eve girdiler. Abdullah b. Ömer onların saçlarını kesti. Abdurrahman el-Asğar Hz. Ömer'in Yemenli hanımı Lüheyye'nin oğluydu. Sonra Amr b. As onlara içki haddi uyguladı ve sopa vurdurdu. Aradan bir müddet geçtikten sonra; Hz. Ömer oğlunun yaptıklarını duydu ve Mısır valisine şöyle yazdı: 'Abdurrahman'ı semerli bir deveye bindir ve bana gönder.' Vali, Halife'nin isteğini yerine getirdi. Çok geçmedi, Abdurrahman el-Asğar Medine'deydi. Hz. Ömer ona seksen sopa had cezası uyguladı ve tekrar Mısır'a gönderdi. Abdurrahman çok geçmeden hastalandı ve bir ay sonra vefat etti. O Mısır'da ölünce halk şu değerlendirmeyi yaptı: Abdurrahman'ın ölümü, Amr b. As'ın değil, Ömer'in onu sopalamasındandır." (Sarıcık 2009: 405-406).
\end{abstract}

Hikâyeye konu olan bu olay H. 14 (M. 635) yılında gerçekleşmiştir. O tarihte içki içmekten dolayı sadece iki kişi had cezası almıştır. Bu olay Müslümanlar arasında unutulmayıp İslam'da adalet anlayışına örnek olarak yüzyıllarca anlatılmıştır ve Türk edebiyatında da hikâyeleştirilerek halk meclislerinde anlatılmıştır.

\subsection{Eserin Özeti}

Şuhmâ, Hz. Ömer'in oğludur. Güzel yaratılışlı ve güzel sesli bir insandır. Sesi, Hz. Muhammed'e benzer ve bütün sahabeler tarafından çok sevilir. Çok görgülü ve tanınmış bir kimsedir. Güzel sesiyle Kur’ân okuduğunda herkes ona hayran kalırdı. Şuhmâ, 
bir gün yine mecliste Kur'ân okumaya gider. 0 , Kur'ân okurken genç yaşlı herkes için için ağlar. Şuhmâ, oradan çıkıp evine giderken yolda bir Yahudi'ye rastlar. Yahudi ona: "Benzin neden böyle sarı." der. Şuhmâ: "Çünkü bir yıldır rahmetten uzağım." der. Yahudi ona: "Gel sana şerbet vereyim hastalığın düzelsin.” der. Şuhmâ'yı alıp evine götürür ve ona içecek verir.

Şuhmâ, Yahudi'nin verdiği içeceği içince sarhoş olur. Yolda giderken bir kadına rastlar ve şarabın etkisiyle onunla zina eder. Daha sonra oradan dönüp evine gelir. Kadın, dokuz ay sonra elinde bir çocukla Hz. Ömer'in yanına gelir: "Ey din askerlerinin en büyüğü, bu çocuk senin oğlunundur; götür ona ver." der. Hz. Ömer hemen eve gider ve Şuhmâ'ya o gün meclisten gelirken başına neler geldi, anlat." der. Şuhmâ başından geçenleri bir bir babasına anlatır, olayı doğrular ve tövbe ettiğini söyler. Hz. Ömer bunun üzerine: "Sana ceza vermemiz ve durumu halka bildirmemiz lazım." der. Şuhmâ: "Ey baba, istersen şimdi beni öldür ama çok utanıyorum, kimse duymasın." der. Hz. Ömer: "Utanmadan zina ettin, cezasını çek, bu günah senden gitsin, sonra yine utanırsin." der.

Hz. Ömer, Şuhmâ'yı cezasını çekmesi için meydana götürür ve genç yaşlı herkes oraya toplanır. Hz. Ömer; ey hizmetçi kamçı getir, hiç acıma, Allah'ın emrini yerine getir." der. Hizmetçi, Şuhmâ'nın elbiselerini çıkarır ve kamçıyı vurur, Şuhmâ'nın teni yarılır. İkinci kamçıyı yiyince babasına yalvarır. Üçüncü kamçıdan sonra Allah'a sığınır. Hizmetçi onuncu kamçıyı vurunca insanlar Hz. Ömer'e gelip: "Bu kadarı yeter, Şuhmâ'ya sabır göster." derler. Hz. Ömer: "Onun durumunu benden sormayın.” der.

Şuhmâ, yirmi kamçı yiyince: "Baba, içim yandı." der. Kamçı otuz olunca halkı dinleyip feryat eder ve zaman ister. Kamçı kırk olunca: "Ey baba, damağım kurudu; bana bir içimlik su ver." der. Hz. Ömer: "Cehennem halkı susadı̆̆ı zaman su ister ama kimse vermez." der. Hizmetçiye: "Ey hizmetçi, kamçı elliye ulaşsın. Sen, Şuhmâ'nın ne dediğine bakma." der. Şuhmâ annesini görmek ister. Altmışıncı kamçıdan sonra Şuhmâ: "Ey bana, yüzünü neden benden çevirdin? Bana bir bak da bari senin yüzünü göreyim." der. Hz. Ömer: "Bugün sana yanaşmam ancak korkarım ki yarın da senden ayrı düşeceğiz." der. Kamçı yetmişe ulaşınca Şuhmâ: "Ey dostlarım beni dinleyin, dediğimi yapın." der. İnsanlar: "Biz senin için canımızı veririz ancak baban bizi dinlemez." derler. Kamçı seksene ulaşınca annesine haber verilir. Annesi gelip için için ağlar: "Ey Ömer, insan evladına böyle mi yapar?" der. Hz. Ömer: "Sen sabret, ne yapalım. Tanrı buyruğunu tamamen yerine getirelim." der.

Kamçı doksana ulaşınca Şuhmâ tatlı canını Allah'a teslim eder. Hz. Ömer: "Ey hizmetçi, on tane daha vur, ceza tamamlansın.” der. Yüz kamçı tamamlandıktan sonra 
Hz. Ömer gelip oğlunu çözer ve ona sarılıp öper. Daha sonra onun cenaze namazını kılarak onu defnederler. $\mathrm{O}$ gece Hz. Ali, Şuhmâ'yı rüyasında görür. Şuhmâ, Hz. Muhammed'in yanında cennet elbisesi giymiş ve başına parlak mücevherden taç takmış. Hz. Muhammed, Hz. Ali'ye: “Ey Ali, Ömer'in bu canı gönlümüzü hoş etti." der. Şuhmâ: “Ey Ali, sen bu durumu babama anlat; ben ondan razıyım. Nasıl beni günahlarımdan arındırdıysa Allah da onu günahlarından arındırsın." der. Hz. Ali uyanınca bu durumu Hz. Ömer'e anlatır. Ömer: "Allah yolu işte böyledir. Canıma şükürler olsun ki hem Peygamber hem de oğlum benden razı olmuş. Oğluma iyi babalık yapmışım.” der ve hikâye bu şekilde sona erer.

\subsection{Eserdeki Şahıs Kadrosu}

Hikâyedeki kişiler olaydaki önem sırasına göre verilecektir:

\section{Şuhmâ (Şuhmât)}

Hikâyenin kahramanı Şuhmâ'dır. Şuhmâ, Hz. Ömer'in Abdurrahman adlı ve Ebu Şahme künyesiyle tanınan oğludur. Hikâyeye göre güzel yaradılışlı ve güzel sesli bir insandır. Mecliste Kur'ân okuduğunda genç yaşlı herkesin gözü dolmaktadır. Bir gün meclisten eve dönerken bir Yahudi'ye rastlar. Yahudi onu benzin neden sarı, gel sana bir şerbet vereyim diyerek kandırır ve içki içirir. Sarhoş olan Şuhmâ içkinin etkisiyle yolda bir tarlada rastladığı bir kadın ile zina eder. Kadın dokuz ay sonra elinde bir çocuk ile Hz. Ömer'e gelip durumu söyler ve çocuğu ona verir. Bundan sonra Şuhmâ'ya İslam şeriatına göre 100 kamçı cezası uygulanır. Bu ceza sonucunda ölür. Hz. Ali rüyasında onu peygamberin yanında ve cennet elbisesi içinde görür. Şuhmâ, Hz. Ali'ye babasını çok sevdiğini, ondan razı olduğunu söyler. Çünkü günahlarının bedelini dünyada ödemiş, öteki dünyaya günahsız olarak gitmiştir.

Destân-ı Şuhmâ, trajik bir konuyu ele alan bir hikâyedir. Fakat Şuhmâ, bu dünyadaki günahlarından arınmış ve öldükten sonra cennete gitmiştir. Hikâyede, bu türden diğer İslami konulu hikâyelerde olduğu gibi bu dünyanın geçiciliği asıl önemli ve ebedî olanın öteki dünya olduğu fikri işlenmektedir. Şuhmâ, Hz. Ömer'in yani İslam'ın ikinci halifesinin oğludur. Buna rağmen cezası uygulanmış ve bunun sonucunda ölmüştür. Hikâyede verilmek istenen mesaj da herkesin adalet karşısında eşit olduğu düşüncesidir. Hz. Ömer'in oğlu olsanız bile hukuk kuralları karşısında eşitsiniz. Hikâye Hz. Ömer'in adalet anlayışını ve dolayısıyla ilk halifeler dönemindeki İslam hukukunu göstermesi dolayısıla önemlidir. 


\section{Hz. Ömer}

Hz. Ömer, hikâyede İslam hukukunun uygulayıcısıdır. Oğlunun zina yaptığını öğrenir öğrenmez oğluna bu durumu sorarak doğruluğunu öğrenir. Doğruluğundan emin olduktan sonra hiç vakit kaybetmeden halka duyurur ve oğluna had vurmak cezasını uygular. Ceza sırasında oğlunun bütün acılarına ve yalvarışlarına aldırmaz. İslam şeriatının dosdoğru uygulanmasını sağlar. Ceza bittikten ve oğlu öldükten sonra gidip ona sarılır. Keşke baban dünyaya gelmeseydi ve başına bunlar gelmeseydi, der. Ancak Hz. Ömer için Allah'ın şeriatını uygulamak ve bu kurallara bağlı kalmak her şeyden önemlidir.

Hz. Ali, gece rüyasında Şuhmâ'yı cennette görür ve bu durumu Hz. Ömer'e bildirir. Hz. Ömer, bu sözleri duyunca oğluna çok iyi babalık yaptığı için sevinir. Hikâyede dolaylı olarak bu dünyadaki günahlarımızın cezasını bu dünyada çekip ödersek öteki dünyada günahlardan arınmış olarak ebedî mutluluğa kavuşacağımız da anlatılmak istenmiştir. Hz. Ömer hikâyede meşhur adaleti ile öne çıkmış ve gerçek İslam hukukunun nasıl olması gerektiğine örnek teşkil etmiştir. Hz. Ömer ve oğlu arasında geçen bu olay insanlara ibretlik bir olay olarak anlatılmıştır.

\section{Yahudi}

Yahudi'nin hikâyedeki kimliği açık değildir. Bu tür hikâyelerde genellikle görüldüğg̈ üzere her türlü kötülüğün ve fitnenin kaynağıdır. Örnek bir hayat yaşayan Şuhmâ’yı kandırarak ona içki içirip sarhoş eder. Sonrasında gelişen olaylar Şuhmâ'nın ölümüne kadar gider. Yahudi tipi masallardaki tek yönlü kötü karakter gibidir. İşi gücü sürekli iyi insanlara kötülük etmektir.

\section{Kadın}

Hikâyede kimliği açık olarak verilmemiştir. Şuhmâ, sarhoş olarak eve dönerken ona tarlada rastlar ve onunla zina yapar. Kadın bu sırrı saklayacağını söylemesine rağmen dokuz ay sonra bir çocuk doğurunca onu alıp Hz. Ömer'e gelir. Oğluyla aralarında geçenleri anlatır ve çocuğu Hz. Ömer'e verir. Hikâyede bunun dışında üzerinde çok durulmamıştır.

\section{Hz. Ali}

Hz. Ali'nin adı sadece hikâyenin sonunda geçmektedir. Hz. Ali, Şuhmâ’yı defnedildiği gün rüyasında görür. Cennete gitmiş, Peygamber'in yanındadır. Ona babasından razı olduğunu söyler. Allah'ın babasına merhamet etmesini, onu günahlarından arındırmasını söyler. Hz. Ali bu durumu Hz. Ömer'e söyler, o da çok sevinir. Hz. Ali 
hikâyede gerçek dünya ile öteki dünya arasında bir aracı gibidir. Hikâyede fazlaca bir rolü yoktur.

\section{Eflah (Hizmetçi)}

Hizmetçi, 100 kamçı cezasının uygulayıcısıdır. Hz. Ömer'in emrini dinlemektedir. Hz. Ömer ona Allah'ın emrini gözetmesini, Şuhmâ'yı dinlememesini sık sık söyler.

\section{Peygamber}

Hz. Muhammed hikâyede İslam dininin peygamberi ve arzu edilen kişi olarak yer almaktadır. Şuhmâ ölünce cennette Peygamber ile görüşür. Peygamber, Hz. Ali'ye rüyada Ömer'in bu oğlundan çok memnun olduklarını söyler. Peygamber, hikâyede çok fazla geçmemekte, hikâyenin sonunda kavuşulan, arzu edilen kişi olarak öne çıkmaktadır.

\section{Halk (İnsanlar)}

Hikâyede figüran rolünde olan insanlar, Şuhmâ'yı çok sevmektedirler. Ancak ceza alınca Hz. Ömer'e yalvarıp yakarmalarına rağmen onu engelleyememişlerdir. Şuhmâ'nı güzel yüzlü ve güzel sesli olması, güzel Kur'ân okuması insanları derinden etkilemektedir.

\subsection{Eserin Nüshası}

Eserin bilinen tek nüshası Ankara Millî Kütüphane Yazmalar Koleksiyonu 06 Mil Yz A 6823/2 numarada kayıtlıdır. Yazma derleme yoluyla oluşturulmuş bir hikâye mecmuasıdır. İçinde 9 halk hikâyesi vardır. Eser yazmanın 5b-8b varakları arasında kayıtlıdır. Yazmanın ikinci hikâyesidir. Eserin adı katalogda yanlış okunarak Destân-ı Şehinşah olarak verilmiştir. Eserin yazmadaki adı Destân-ı Şuhmầ'dır.

Eser abadî kâğıda harekeli nesih yazısıyla her sayfada 15 satır olarak yazılmıştır. Yazmanın ölçüleri 206x150 mm (187x125 mm) şeklindedir. 1992 y1lında Abdülmecid Güldü'den satın alınmıştır. Oldukça yıpranmış bir yazmadır, ilk iki sayfası yırtık ve şirazesi dağılmıştır. Yazma şemseli, köşebendli, yıpranmış desenli bir mukavva cilt içerisindedir.

\subsection{Eserin Yazarı: Aksaraylı Îsâ}

Eserin yazarı hikâyenin 100 . beytinde açıkça belirtilmiştir:

aḳsarāylu 'īsā tevzik iyle sen 
dün-ile yalvar hakḳa çoḳ inle sen

“Aksaraylı İsa, çabuk ol sen. Gece ile Allah'a yalvar, çok ağla sen."

Aksaraylı Îsâ hakkında kaynaklarda bilgi bulunmamaktadır. Muhtemelen XIV. yüzyılda yaşamış meddâh bir şair olmalıdır. Araştırmalara göre Aksaraylı Îsầya ait olduğu düşünülen dört eser vardır:

1. Hikâyet-i Şuhmâ

2. Miraçname ${ }^{1}$

3. Dâstân-1 İsmail

4. Kissa-i İbrahim

Aksaraylı Îsâ'nın eserlerinden onun Arapça ve Farsça gibi dillere vâkıf olduğu anlaşılmaktadır. Eserleri dinî ve ahlaki bir çizgidedir. İslamî konularda bu gibi küçük eserler oluşturarak halk meclislerinde icra etmiştir. Beylikler ve Osmanlının Kuruluş Dönemi'nde yaşamış olmalıdır. Adından anlaşıldığı üzere Konya ve Aksaray civarlarında yaşamıştır.

Meddâh şairler eski destancıllk geleneğini devam ettirmekle birlikte genellikle iyi bir eğitime sahiptirler. Eski edebiyatın henüz kurumsallaşmadığı bir dönemde bu gibi hikâyeler yazarak halka İslamiyet'i sevdirmeye ve halk içinde İslam'ın yaygınlaşmasına çalışmışlardır. Bu şairler bir yönüyle de halk meclislerinde hikâyeler okuyan gezgin dervişler sayılabilirler.

Aksaraylı Îsâ'nın eserlerindeki dil oldukça sade ve akıcı bir halk dilidir. Basit halk ruhuna uygun olarak dinî ve ahlaki hikâyeler oluşturup kasaba ve köylerde bunları halk meclislerinde okumuştur. İslam'ı halka sevdirip basit dinî kuralları halka anlatmak için bu tarz basit hikâyeler oluşturmuştur. Amaç halka dinî sevdirmenin yanında bu hikâyeler aracıllğ̆ ile insanlara kıssadan hisse vermektir. Bu tür eserlerde genellikle bu dünyanın faniliği, asıl ve ebedî olanın öteki dünya olduğu ve bu nedenle ölmeden önce ölüme hazırlanma fikri yaygın olarak işlenmiştir.

Eski edebiyatımızda bu tür manzum halk hikâyeleri üzerine yapılan çalışmalar çok fazla değildir. Kaynaklar araştırıldığında Aksaraylı Îsâ'ya ait başka hikâyelerin çıkması büyük bir olasılıktır.

1 Miraçname nüshalarında Aksaraylı Îsâ'nın adı geçmemektedir. AKAR, Süleymaniye Kütüphanesi Laleli 3756 numarada yer alan yazmadaki başka bir hikâyeden hareketle bu eserin Aksaraylı Îsâ'ya ait olabileceğini belirtmiştir (1987: 155-157). 


\subsection{Eser Üzerine Yapılan Çalışmalar}

Eser üzerine yapılan hiçbir çalışma yoktur. Hikâye, ilk kez bu çalışma ile gün yüzüne çıkmakta ve bilim âlemine tanıtılmaktadır.

\section{Eserin Dili ve Anlatımı Üzerine Notlar}

Hikâyet-i Şuhmâ, Eski Anadolu Türkçesi dil özellikleri taşımaktadır. Hikâyenin XIV. yüzyılda yazıldığı tahmin edilmektedir. Eserde dikkat çeken belli başlı dil ve anlatım ile ilgili özellikler şu şekildedir:

1. II. tekil şahıs zamiri sen bir yerde $\sin$ (092)olarak yazılmıştır.

2. di- fiili eski yazımda sürekli /i/'li olarak yazılır. Fakat metinde iki yerde (022, 059) /e/'li olarak harekelenmiştir.

3. Metinde bazı yuvarlak ünlülü harflerden sonra fazlalık bir elif harfi vardır. Bu kullanımlar Kur'ân imlasının bir yansımasıdır. Vav+elif yapısına örnekler şu şekildedir:

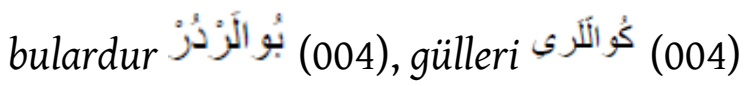

4. /i/ /e/ değiş̧ikliği Eski Anadolu Türkçesi zamanındaki en önemli değişikliklerden birisidir. Günümüzde /e/ olarak yazılan pek çok kelime o dönemde /i/ ile yazılmıştır. Metinden bazı örnekler şu şekildedir: didi (018), diyü (053), yitmiş (065), virdi (034), vireyim (021).

5. /t/ /d/ değişikliği Eski Anadolu Türkçesinde yaygın olarak görülmekle birlikte metnimizde bu değişikliğe örnek yoktur. Kelimeler /t/ veya /d/'li olarak tek şekilde kullanılmıştır: daǵla- (078), dapız- (015), datlu (083), ditre- (029), țoǵ- (026), țoksan (074), țokun- (048), țokuz (026), țon (045)

6. Bildirme görevindeki durur kelimesi metinde iki kez geçmektedir. Bunun d1şındaki örneklerde kısalarak \{-dUr\} şekline dönüşmüştür. Bildirme görevindeki durur kelimesi XIV. yüzyıldan sonra daha çok arkaik olarak kullanılmıştır: oǵluy durur (027), var durur (033)

7. Eski Anadolu Türkçesinde genellikle yuvarlak şekilde geçen bazı ekler metnimizde düz ünlülü olarak kullanılmıştır. Bu kullanımlara bazı örnekler şu şekildedir:

\{-AlIm\}: çal-alım (025).

\{-dIm\}: kıl-dım (036), çılk-dım (036), getür-dim (028), iç-dim (034).

$\{-\operatorname{Im}\} /\{-\operatorname{ImIz}\}: b \bar{a} \dot{g}-\imath m$ (081), cān-ım (071), cān-ımız (068). 
\{-nIy\}: bā $\dot{g}-\imath n ı \eta ~(004)$.

8. Eski Anadolu Türkçesinde yuvarlak olarak kullanılan eklere metnimizden bazı örnekler şu şekildedir:

\{-dUr\}: bu-dur (102), yok-dur (079), böyle-dür (080), nice-dür (009).

\{-AlUm\}: it-elüm (idelüm) (068), gör-elüm (061), işit-elüm (işidelüm) (015).

\{-Um\}: bülbül-üm (081), gül-üm (081).

\{-UbAn\}: ol-uban (023), düş-üben (075).

\{-Up\}: çaġır-up (067), ḳll-up (072), țut-up (099).

9. Eserin dili oldukça sade ve akıcı bir halk dilidir. Bu tür eserler deyim, ikileme, arkaik ve ağız özelliği taşıyan kelimeler açısından önemli metinlerdir. Metinde yer alan deyimlerden bazıları şu şekildedir: cān vir- (099), cānı hakḳa vir- (074), yürekin dag̀la- (078).

10. Eserin dili her türlü yapmacıktan uzak doğal ve sade bir halk dilidir. Basit halk ruhuna uygun olarak yazılan ve halk meclislerinde okunan bu tür hikâyeler yüzyıllarca sevilerek okunmuş ve günümüze taşınmıştır. Aşağıda verilen beyitler eserin saf ve doğal dilini yansıtan birkaç örnektir:

çün șaǵıldı mescide geldi yine

halk üşe geldi ḳamu kim başına (014)

gel saya şerbet vireyim içesin

țola beyzin hastelikten geçesin (021)

ey benim göylüm yemişi ‘ayālüm

tayrı emri böyledür n'eyleyelüm (080) 


\section{Transkripsiyonlu Metin ve Çeviri}

$[5 b]$ hazāa destān-1 şuhmā (ḥikāyet-i şuhmā)

001 bir hikāyet eydeyin yāranlara şeric içinde doğru yola varanlara

002 şeric içinde nice dog̉r gitdiler dünyā içün işit neler itdiler

003 dīn evinin dört dīvārıdır bular hem ebū bekir ‘alĩ oșmān ‘ömer

004 hem bulardur dīn bāg̀ının gülleri mușțafā gülzārınuy bülbülleri

005 şeri` bular āşikāre ḳıldılar biz yara şericin ḳılıcını șaldılar

006 dünyā denizdür şerī‘at bir gemi gark itmeye aya giren ādemi

007 ol gemiye girmeyen gark olısar ol dahı̆ı nūḩ ḳavmi gibi ḳalısar

008 ger saya ben şerici taḳdīr eyleyem işbu sözin ḳamısını söyleyem

009 işit imdi işbu sözden bir ḩaber şeri` içinde nicedür imdi cömer

010 var idi bir oğlı adı şuhmā idi hulkı hūb hem hūb-āvāzlu idi

011 muștafā ününe beyzerdi üni șahābeler cümlesi sever idi anı

012 muștafādan șoyra işitilmedi hergiz ${ }^{2}$ andan görgülü ünli gelmedi

013 āvāz-ıla ḳurān oḳurdı her dem āvāzına ḥayrān olurdı her ādem

\section{Şuhmâ’nın Hikâyesi}

Dostlara ve dinin kuralları içinde doğru yola gidenlere bir hikâye anlatayım.

Dinin esasları içinde nasıl doğru yola gittiler. Dünya için neler yaptılar, dinle.

Ebu Bekir, Ali, Osman ve Ömer dinin evinin dört duvarıdırlar.

Bunlar, din bağının gülleri ve Mustafa'nın gül bahçesinin bülbülleridir.

Bunlar, dinin kurallarinı ortaya koydular ve biz dostlara dinin kılıcını biraktılar.

Dünya bir deniz, şeriat ise bir gemidir; ona binen insanı batırmaz.

o gemiye binmeyen suya batar ve o da Nuh kavmi gibi helak olur.

Ben sana dinin kurallarının değerini anlatayım ve bu sözün tamamın söyleyeyim.

Şimdi bu sözden bir haber dinle ve şimdi dinin emirleri içinde Ömer'in nasıl olduğunu (gör).

Onun bir oğlu vardı, adı Şuhmâ’ydı. Güzel yaratılışlıydı ve güzel bir sesi vardı.

Sesi, Mustafa'nin sesine benzerdi, sahabelerin hepsi onu severdi.

Mustafa'dan sonra ondan daha görgülü ve taninmış biri asla gelmedi ve duyulmadı.

Her vakit yüksek sesle Kur'ân okurdu. Herkes onun sesine hayran olurdu.

2 hergiz: Metinde hergez diye harekelenmiş. 
014 çün șaǵıldı mescide geldi yine halk üşe geldi ḳamu kim başına

015 eyitdiler şuhmāya dapıy emir ķurān oḳu işidelüm bir caşir

\section{[6a]}

016 çünki bu şuhmā oḳudı bir aşir zārı zārı ağladılar yigit ü kebīr

017 çün du'ā ḳlur ḩalāyık ag̉layur gör bu şuhmāya ne vaḳı cāt olur

018 eve giderken șataşdı bir yahūd niçün beyzüy șarı didi ol ḥasūd ${ }^{3}$

019 eytdi bu şuhmā aya kim șarıyım bir yıl oldı rāḥmetden ārīyım ${ }^{4}$

020 ol yahūd eydür ana ḳayırmag்ıl ben ne dirsem sözümi sen șımaġıl

021 gel saya şerbet vireyim içesin țola beyzin hastelikten geçesin

022 ol yahūdī şuhmāyı iletdi eve șuyım iç dedi hep derde devā

023 çün bu şuhmā șuyı içdi gör n'ider içdi sekrān oluban eve gider

024 yolda bāg içinde bir 'avrat bulur süci fi'liyle aya gör ne ḳılur

025 'avrat eydür gizleyem bu sözi ger çalalım içmez isey bu süci

026 çün țokuz ay geçer bir og̉lan țoġar 'avrat alur anı 'ömere gelür
Yine hızh bir şekilde mescide geldi, bütün herkes başına toplandı.

Şuhmâyya: "Emre tabi ol, Kur'ân'dan ayetler oku, (biz de) dinleyelim." dediler.

Şuhmâ ayetler okuduğu zaman genç yaşl herkes için için ağladı.

Halk dua edip ağlarken bu Şuhmầnın başına neler gelir, gör.

Eve giderken bir Yahudi ona rastladı. O haset: "Neden benzin sarl?" dedi.

Bu Şuhmâ ona: "Sarıyım çünkü bir yıldır rahmetten uzağım." dedi.

o Yahudi ona: "Üzülme, ben sana ne dersem, sakın beni kırma.

Gel sana şerbet vereyim iç, benzin yerine gelsin ve hastalı̆̆ın geçsin."

o Yahudi, Şuhmâ'yı eve götürdü: "Suyumu iç, her derde devadir." dedi.

Bu Şuhmâ suyu içince bak ne yapar. (Suyu) içince sarhoş olup evine gider.

Yolda bahçe içinde bir kadına rastlar. Şarabın etkisiyle kadına bakne yapar.

Kadın: "Ben bu sırrı saklayayım. Eğer şarap içmezsen bari çalıp oynayalım." dedi.

Dokuz ay geçtikten sonra bir oğlan doğar. Kadın, o çocuğu alarak Ömer'e gelir: 
027 eydür ey dīn leşkerinüy ā'lās1

senin og̉luy durur oǵlan issi

$028 \quad$ kıldı bu şuhmā benim ile zina

uş getürdim oğlanı virüy aya

029 beyzi șoldı anı işitdi 'ömer

ditredi geldi eve gör ki n'ider

030 ‘ömer eydür yā og̉ul düşdi sefer

doğrı it kim diyim çün bir haber

031 şol gün kim mescide ḳurān oḳuduy

ol baya itgil sen ḳanda idün

032 eydür ey baba eve gelür idim

yolda ol fülān yahūda uggradım

[6b]

033 eydür baya nite beyzin șarı durur

bende bu derdin devāsı var durur

034 aldı girdi evine virdi şarāb

bilmedim içdim anı oldum harāb

035 çıḳdım ol yahūd evinden ey ata

bāg içinde ug̉radım bir 'avrata

036 ḳ1dım ol 'avrat ile şol dem zina

illā tövbe ḳıldım ol işden yine

037 cömer eydür sana had urmak gerek hem bu sözi halḳa bildürmek gerek

038 eydür öldür şimdi ey baba beni utanırım kimse duymasın bunı

039 eydür utanmayup ḳıldındı zinā had ur çıkssın utanursın yine

040 'ömer eydür tayrı haddini uram muștafāā şercini yerine getürem

041 iletdi bu şuhmāyı meydan içine tā cezāsın vire lāyık șuçına
"Ey din askerinin en büyüğü, bu çocuğun sahibi senin oğlundur.

Bu Şuhmâ benim ile zina etti. İşte şimdi bu çocuğu getirdim, (götürüp) ona verin." der.

Ömer bu sözü işitince benzi soldu, titredi. Eve geldi, bak şimdi ne yapar.

Ömer: "Ey oğul, sana yolculuk düştü. Sana bir haber soracağım, bana doğrusunu söyle.

Mescitte Kur'ân okuduğun o gün sen neredeydin? Bana söyle."

"Ey baba, eve geliyorken yolda filanca Yahudi'ye rastladım.

Bana: 'Benzin neden sarıdır, bende bu derdin devası vardır.' dedi.

Aldı beni evine götürdü, şarap verdi. Bilmeden onu içtim ve sarhoş olup perişan oldum.

Ey baba, o Yahudi'nin evinden çıktım, bağ içinde bir kadına rastladım.

O kadın ile o vakit zina yaptım. Sonra yine o işten tövbe ettim."

Ömer: "Sana ceza vermek ve bu durumu halka bildirmek gerek." dedi.

"Ey baba, şimdi beni öldür, utanıyorum, kimse bunu duymasin." dedi.

"Utanmadan zina ettin. Cezasını çek, bu günah senden çıksın, sonra yine utanırsın." dedi.

Ömer: "Tanrı'nın belirlediği cezayı vereceğim ve Mustafa'nın şeriatını yerine getireceğim." dedi.

Bu Şuhmầyı suçuna layık cezasını vermek için meydana içine götürdü. 

ḳamu cālem meydāna dizildiler eyitdi saya șığındım ey pādişāh

\section{[7a]}

049 çünki eflāh țurrā urdı beş tamām didi el-ḥamdülillāh şükür ve's-selām

050 çün irgürdi eflāh țurrā’ ona cümle yāranlar dirildi yanına

051 yalvaruban eytdiler kim yā ömer șabır idi vir şuhmāya bu yeter

054 çünki bu şuhmā yigirmi țurrā yedi didi kim baba yüregim acıdı

055 țurāā otuza iricek dinledi kavmi feryād itdi mühlet diledi

056 çünki țurrā ḳırḳa degin yörüdi eydir ey baba damaġım ḳurudı
Bütün halk meydana toplandilar ve oraya dizildiler.

Genç yaşli, kadın erkek herkes toplandı. Şuhmấyı görünce ağlamaya başladılar.

Ömer, hizmetçiye: "Kamçı getir, hiç sevgi gösterme, Tanri cezasinı ver." dedi.

Hizmetçi, Şuhmâ'nın elbisesini çıkardıktan sonra öyle bir kamçı vurdu ki vücudunu yardı.

Şuhmâ, göğsünü iyice açtı ve ey kerem sahibi, ey esirgeyen Allah diye bağırmaya başladı.

İki kamçı vurulunca çok inledi. Ömer'e yalvardı, zaman istedi.

Üçüncü kamçı vurulunca ah etti: "Ey Allah'ım, sana sığındım." dedi.

Hizmetçi beşinci kamçıyı vurunca: "Allah'a şükürler olsun, işte bu kadar." dedi.

Hizmetçi onuncu kamçıyı vurduğu zaman bütün dostlar yanina toplandl.

Yalvararak "Ey Ömer, Şuhmầya sabır göster, bu kadarı yeter." dediler.

Ömer: "Bu Şuhmẩnın durumunu benden sormayin.

Ey hizmetçi; kamçıyı vur, acıma. Ölür diye hiç endişe edip kayglanma."

Şuhmâ, yirmi kamçı yiyince: "Baba, içim yandı." dedi.

Kamçı otuz olunca halkı dinledi, feryat edip zaman istedi.

Kamçı kırka kadar varınca: "Ey baba, damağım kurudu. 
057

baya bir içim șu virsünler buyur kim bile ölem beni șuya doyur

058 cömer eydür țamu ehli șuṣaya șu dileye illā kimse virmeye

059 cömer eydür țurrā irsün elliye sen işitme bu şuhmā ki ne deye

060 şuhmā eydür ey baba anam ḳanı ölürem gelsün hāālim görsün beni

061 biribirimiz görelüm ölmeden ben aya ol baya hasret ḳalmadan

062 ömer eydür ur yā eflāḥ altmışı allāh emrin gözle ḳo ayruḳ işi

063 eydür ey baba niçün döndi yüzüy bu baya bak göreyim bārī gözin

[7b]

064 'ömer eydür saya buluşmam bugün ḳorḳaram ayru düşelim yarınḳı gün

065 'ömer eydür țurrā irsün yitmişe allāh emrine ḳā'īm ol hak işine

066 eydür ey yāranlarım bağışlanuz her biriyüz didigüm işleyüz

067 çün yāranlar bu sözi işitdiler çaġırup başlarını açdılar

068 biz seninçün cānımız terk idelüm illā çün atay işitmez n'idelüm

069 'ömer eydür țurrā irsün seksene haber olsun ol ża'îf anasina

070 baş açık yalın ayak geldi ana geldi halk üşmiş bu şuhmā üstine

071 zārı zār ağlar eydür ey og̉lanum bu ne vaḳı '́a idi saya cānım
Buyur bana bir içimliksu versinler. Belki ölürüm, beni suya doyur."

Ömer: "Cehennem halkı susadığı zaman su ister ancak kimse vermez." der.

Ömer: "Kamçı, elliye yetişsin. Bu Şuhmâ'nın ne dediğine sen bakma." dedi.

Şuhmâ: "Ey baba, annem nerede? Ölüyorum, gelip benim hâlimi görsün.

Ölmeden önce birbirimizi görelim. Ben ona, o bana hasret kalmasin.

Ömer: "Ey hizmetçi, altmışı vur. Allah emrini gözet, başka işi bırak." dedi.

"Ey baba, yüzünü neden çevirdin? Bir bana bak, bari senin gözünü göreyim." dedi.

Ömer: "Bugün, seninle bir araya gelmem. Korkarım ki yarın da ayrı düşeceğiz." dedi.

Ömer: "Kamçı yetmişe ulaşsin. Allah'in emrine sebat et." dedi.

"Ey dostlarım, beni bağışlayın; her biriniz dediğimi yapın.”

Dostlar bu sözü duydukları zaman feryat edip başlarını açtılar:

"Biz senin için canımızı bile veririz ancak baban dinlemez, ne yapalım."

Ömer: "Kamçı seksene ulaşsin. O garip anasına haber verilsin." dedi.

Anası baş açık, yalın ayak geldi. (Baktı ki) halk Şuhmầnın etrafina toplanmış.

İçin için ağlayıp: "Ey oğlum, ey canım benim bu ne beladır ki başına geldi." 

'ayālin kimse bu hāalde mi ider

073 'ömer eydür sen șabır it n'eyleyelüm tayrı buyrugin tamām eyleyelüm

074 çün tamām urdı eflāh țoksan virdi bu şuhmā ḥaḳka datlu cānı

075 anasınıy ușșı gider düşüben aǵladılar halk üstine üşüben

076 ‘ömer eydür yā eflāh on dahı ur ne vara eger öldise haddin yeter

077 yüzțurrā’ tamām urdi (ömer geldi og̉lun şeşdi ol şīr-ü ner

078 yüzin urdı yüzine çok ag̉ladı şöyle kim halḳııy yüregin daġladı

079 ey benim gözümün nūrı pāresi tạrı hükmidür yoḳdur bunuy çāresi

080 ey benim göylüm yemişi ‘ayālüm tayrı emri böyledür n'eyleyelüm

\section{[8a]}

081 ey benim bülbül nefeslü bülbülüm ey benim bāğım bākçem reyhānım gülüm

082 allāhıy emrine muhkem düşmişem ey cezāsın bu cihānda bulmışım

083 ey benim bağrım pāresi cigerim ey yigitlikde giden datlu cānım

084 keşke ‘ömer dünyāya gelmeseydi saya bu vaḳı ‘alar olmasaydı

085 çünki haḳḳıı emridür n'itmek gerek allāh emrine boyun egmek gerek

086 arı yudılar kefine șardılar senden yaya haḳka gönderdiler
Ağlayıp feryat ederek: "Ya Ömer, hiç kimse evladını bu hâle getirir mi?" der.

Ömer: "Sen sabret, ne yapalım. Tanrı buyruğunu tamamen yerine getirelim." dedi.

Hizmetçi, doksan kamçıyı tamamlayınca bu Şuhmâ tatlı canını Allah'a teslim etti.

Anası kendini kaybederek düşüp bayılır. Halk üstüne toplanarak ağlar.

Ömer: "Ey hizmetçi, on tane daha vur. Eğer öldüyse ne olur, cezası biter." dedi.

Yüz kamçı tamamlandı. O erkek aslan gibi olan Ömer gelip oğlunu çözer.

Yüzünü yüzüne dayayıp o kadar çok ağladı ki herkesin içi yandl.

"Ey benim gözümün nuru, (yüreğimin) parçası, Tanri emridir, bunun çaresi yoktur.

Ey benim gönlümün meyvesi, evladım, Tanr emriböyledir, ne yapalim.

Ey benim bülbül nefesli bülbülüm, ey benim bağım bahçem, reyhanım, gülüm,

Allah'in emrine bağlı kalmışım. Ey cezasını bu dünyada çekenim,

Ey benim yüreğimin parçası, ciğerparem, ey genç olarakölen tatlı canım,

Keşke Ömer dünyaya gelmeseydi. Senin başına bu belalar gelmeseydi.

Madem bu Allah'in emridir, ne yapmak gerek. Allah'ın emrine boyun eğmek gerek."

(Şuhmầyı) temizce yıkayıp kefene sardılar. Allah'a doğru toprağa verdiler. 
uyḳuya vardı ‘alī düşde görür çün bu şuhmā mușțafā ile țurur

başına güher nūrdan tāc urur yüzi ay hem güneşçe görünür

090 hülle giymiş hem nūrdan güzel olur çün görür 'alī anı hayrān ḳalur

091 resūl eydür calìye kim yā calī hoşnūd eyledi bizi ‘ömer cānı

092 döndi bu şuhmā eydür kim yā calī atama söyle sin bu aḥvāli

093 ben atamdan ḩoşnūd olmışım tamām yedi uçmaḳ olsun ana dārü's-selām

$094 \quad$ nite kim yazıkdan arıtdı beni hak günāhından şöyle arıtsın anı

095 çün uyandı bu sözi didi ‘ alī ‘ömer eydür şöyledür allāh yolı

096 ömer eydür şükür minnet cānıma hoş atalık eylemişim og̉luma

$[8 \mathrm{~b}]$

097 çün og̉lan olmış benden şākir hem şākir olmış resūl benden şükür

098 ma'şūk içün gör ‘āşıḷlar ne ḳılur çün ‘āşıḳlar hālini kim ne bilür

099 kimi dīn dönderür kimi cān virür kimi emrin tutup og̉lun öldürür

100 aḳsarāylu ‘̄isā tevžik iyle sen dün-ile yalvar haḳka çoḳ inle sen
Orada namazını kıldılar ve Kur'ân'ı baştan sona okuyup bitirdiler.

Ali, uyuyunca düşünde Şuhmẩnın Mustafa ile durduğunu görür.

Başına parlak mücevherden taç takmış, yüzü de ay ve güneş gibi görünür.

Güzel, parlak ve ışıltılı bir cennet elbisesi giymiş. Ali, onu görünce hayran olur.

Peygamber, Ali'ye: “Ey Ali, bu Ömer'in canı, gönlümüzü hoş etti.” dedi.

Bu Şuhmâ dönüp: "Ey Ali, sen bu durumu babama bildir.

Ben babamdan sonuna kadar razıyım. Yedi cennet ona mekân olsun.

Benigünahımdan nasıl arındırdıysa Allah da onu günahindan arindirsin.

Ali, uykudan uyaninca bu sözü Ömer'e söyledi. Ömer: "Allah yolu böyledir." dedi.

Ömer: "Canıma şükür ve minnetler olsun. Oğluma iyi babalık yapmışım.

Çünkü, hem oğlum benden razı olmuş hem de peygamber razı olmuş, şükürler olsun.

Sevgili için âşılar ne yapar bir bak ve âşılkların hâlini kim nerden bilir.

Kimi dininden döner, kimi bu uğurda can verir, kimi de Allah’in emrini yerine getirip oğlunu öldürür.

Aksaraylı İsa, çabuk ol sen. Gece ile Allah'a yalvar, çok ağla sen. 
101 işlerinüz cümle hayr ile olsun tamām muștafāya vir șalavāt ve's-selām

102 tā ki ola her ducālar müstecāb söz budur allāhu āclem bi’ṣsṣavāb

103 fācilātün fācilātün fācilāt mușțafānı̀ rūḥına vir șalavāt
Bütün işleriniz hayır ile tamama ersin. Mustafa'ya salavat ver, (hikâye) artık bitti.

Sonunda bütün dualar kabul olsun. Söz şöyledir: "Doğrusunu en iyi Allah bilir."

Fâ'ilâtün Fâ'ilâtün Fâ'ilât, Mustafa'nın ruhuna ver bir salavat.

$\mathrm{m} \mathrm{m}$

Bitti.

$\mathrm{m}$ 


\section{DİZİN}

\subsection{Gramatikal Dizin}

A

acı- (Vücudun bir yeri) Ağrılı olmak, ağrımak, sızlamak; canı yanmak.

a.- $d_{1} 054$

aç- (Bir şeyi) Kapalı, örtülü, kilitli veya bağlı durumdan çıkarmak, görünür duruma getirmek.

a.- $-d_{1} 046$

a.- dilar 067

açık (Vücut veya organ) Çıplak, örtüsüz, üryan.

a. 070

ad Ad, isim.

a. +1010

ādem (< Ar. ādem) İnsan, beşer.

ā. 013

ā.+ i 006

ag̉la- Gözyaşı dökmek, ağlamak.

a.- $d_{1} 078$

a.- dilar 016,075

a.- $\mathrm{r} 071$

a.- yur 017

aǵlaş- Birlikte veya karşılıklı olarak ağlamak.

a.- dilar 043

āh (< Ar., F. āh) Feryat, inilti.

ā. ḳıl- Feryat etmek, inlemek, şikâyet etmek: 048

aḥvāl (< Ar. aḥvāl) Durum, vaziyet, hâl.

a. $+\mathrm{i} 092$ al-1. Herhangi bir şeyi tutup yerinden ayırarak elinde veya yanında bulundurmak: 026 . 2. (Birlikte veya yanında) Götürmek: 035.

a.- $\operatorname{ur} 026$

a.- $d_{1} 035$

$\overline{\mathbf{a}} \mathrm{l} \overline{\mathbf{a}}(<\mathrm{Ar} . \bar{a} \mathrm{q} \bar{a})$ (Daha, en, pek) Yüksek.

$\bar{a} .+$ s1 027

‘ālem (< Ar. 'ālem) Herkes, insanlar.

kamu ' $\bar{a} . \rightarrow$ kamu.

allāh (< Ar. allāh) Allah.

a. $062,065,082,085,095$

a.+ 1 10 083

altmış Altmış sayısı.

a. +1062

ana Anne.

a. 070

a. $+\mathrm{m} 060$

a.+ sina 069

a.+ $\sin 19076$

anda Orada.

a. 087

andan Ondan.

a. 012

anı Onu.

a. $011,026,029,034,090,094$

anıy Onun.

a. 052

aya Ona.

a. $006,019,020,024,028,061,093$

ara Ayrı, uzak.

a.+ yım 019

arı Temiz, arı. 
a. 087

arıt- Temizlemek, kirliliğini gidermek.
a.- d1 094
a.- $\sin 094$

'āşı̣ (< Ar. 'āşıl Â) Âşık, seven.

‘̄..+ lar 098

āşikāre (<F. āşkāre) Açıkça, açık bir şekilde.

ā. ḳıl- Meydana çıkarmak, ortaya koymak, belli etmek: 005

'aşir (< Ar. 'aşir) Kur'ân'dan on ayetlik bir bölümün okunmasi.

'a. 015,016

ata Baba, ata.
a. 035
a.+ ma 092
a.+ mdan 093
a. + ๆ 068

atalık Babalık, atalık, ata olma durumu.

a. eyle- Babalık yapmak: 096

āvāz (< F. āvāz) Yüksek ses.

ā.+ ina 013

ā.+ -1la 014

'avrat (< Ar. 'avrat) Kadın.

er $\ddot{u}^{c} a_{0} \rightarrow e r$.

'a. $024,025,026,036$

ay Ay.
a. 026,089

ayaḳ Ayak.
a. 070

‘ayāl (< Ar. 'iyāl) Çoluk çocuk, evlat.

'a.+ in 072

‘a.+ üm 080 ayru Ayrı, uzak.

a. düş- Ayrılmak: 064.

a. 064

ayruk Başka.

a. 062

'aẓim (< Ar. 'aẓim) İyice, ziyadesiyle.

'a. 046

\section{B}

baba Baba, ata.

b. $032,038,054,056,060,063$

bāğ (<F. bā' $)$ Băg, bahçe, bostan.

b.+ bāḳçe Bahçe: 081

b. 024,035

b. $+1 \mathrm{~m} 081$

b.+ 1nin 004

bağır Göğüs, ciğer, kalp, yürek, karın gibi vücut boşluklarında bulunan organların ortak ad1.

b.+ $1 \mathrm{~m}$ (baǵrım) 083

b.+ 1 nı (bag்rını) 046

baġışla- Affetmek, bağışlamak.

b.- yuz 066

baḳ- Gözleri bir şey üzerine çevirmek.

b. 063

bākçe (< F. bağçe) Bahçe, bostan.

$$
\text { b.+ m } 081
$$

baya Bana.

b. $031,033,058,061,063$

bārī (<F. bārī) Hiç olmazsa.

b. 063 
baş 1. Baş, kafa: 067, 070. 2. Bir şeyin veya bir yerin etrafı, çevresi, yanı: 014 .

b. 070

b.+ 1na 014

b.+ larını 067

ben Ben (1. tekil şahıs zamiri).

b. $008,020,061$

b.+ de 033

b.+ den 052, 097

b.+ i 038, 057, 060, 094

b.+ im 028, 079, 080, 081, 083

beniz Yüz rengi.

b.+ i 029

b.+ in 021,033

b.+ ün 018

beyze- Ortak tarafları sebebiyle birbirini andırmak, hatırlatmak.

b.- rdi 011

beş Beş sayısı.

b. 049

bil- Haberi olmak, vakıf olmak.

b.- e 057

b.- medim 034

b.- ür 098

bildür-Haber vermek.

b.- mek 037

bir (1) Herhangi bir.

b. 001, 006, 009, 015, 016, 018, 024, 026, 030, 035, 057

bir (2) Bir sayıs1.

b. yıl ol- Bir yıl tamamlanmak: 019

b. 010,045 biribiri Birbiri, karşılıklı olarak biri ötekini, öteki de onu.

b.+ miz 062

biz Biz (1. çoğul şahıs zamiri).

b. 005,069

b.+ i 091

boyun Vücudun omuzlarla baş arasında kalan ve başı bedene bağlayan kısmı.

b. eg- Güçlü olanın emrine uymak, itaat etmek: 085.

böyle Böyle, bu şekilde, bunun gibi.

b.+ dür 080

bu Bu (İşaret sıfatı ve işaret zamiri).

b. (İşaret sıfatı) 016, 017, 019, 023, 025, 028, 033, 037, 041, 043, 046, 051, 052, 054, 059, 063, 067, 070, 071, 072, 074, 082, 084, 088, 092, 095

b.+ dur 102

b.+ lar 003, 005

b.+ lardur 004

b. + n1 038

b.+ nuy 079

bugün Bugün.

b. 064

bul- 1. (Kötü davranışları yüzünden) Hak ettiği şeyle karşılaşmak: 082. 2. (Arayarak veya rastgele) Bir şey, bir kimse veya bir durumla karşılaşmak: 024.

b.- mışım 082

b.- ur 024

buluş- Belli bir yerde bir araya gelmek, birbirini bulmak.

b.- mam 064

buyruk Emir, buyruk. 
b.+ $\ln 073$

buyur- Emretmek.

b. 057

bülbül (< F. bulbul) Çok güzel öten, sesinin güzelliğiyle meşhur küçük kuş.

b. 081

b.+ leri 004

b.+ üm 081

\section{C}

cān (< F. cān) 1. İnsan ve hayvanların yaşamasını sağlayan ve ölümle bedenden ayrılan madde dışı varlık, ruh: 068, 074, 099.

2. Sevilen, aziz, sevgili: 071, 083, 091. 3. Gönül, yürek, kalp, iç, iç alem: 096.

c. vir-Ölmek, hayatı sona ermek: 099.

c.+ $\imath$ ḥaḳka vir- Ölmek: 074.

C. +1091

c. $+\operatorname{Im~} 071,083$

c. +1 ma 096

C. $+1 \mathrm{miz} 068$

cezā (< Ar. cezā) Suç işleyen bir kimseye suçunun derecesine göre verilen acı karşılık.

c. vir- (Birisini) Cezalandirmak: 041.

c. $+\sin 041,082$

ciger (< F. ciger) Ciğer, bağır, gönül, yürek.

c.+ im Çok sevilen bir kimse için kullanılan hitap sözü: 083.

cihān (< F. cihān) Dünya, yeryüzü.

c. + da 082

cümle (< Ar. cumle) Bütün, hep.

c. $042,050,101$

C.+ si 011

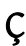

çaġır- Bağırmak, feryat etmek, haykırmak.

ç.- $\operatorname{urd} 1046$

ç.- up 067

çal- Eğlenmek, âlem yapmak.

ç.- $\operatorname{alim} 025$

çāre (< F. çāre) Çare, çıkar yol, çözüm yolu, tedbir, kurtuluş yolu.

Ç.+ si 079

çıḳ- 1. (Bulunduğu yerden) Dışarıya varmak, içerden dışarı gitmek: 036. 2. Yok olmak, kalmamak, zail olmak: 039.

ç.- $\operatorname{dim} 036$

ç.- $\sin 039$

çoḳ Fazla, pek, çok.

ç. $047,078,100$

çün (< F. çun) 1. (Zaman yan cümlesinin başında) Ne zaman ki, -dığı zaman: 023, 026, 067. 2. (Sebep yan cümlesinin başında) Çünkü, madem ki, dolayı, için, şunun için ki, şundan dolayı: 097, 098.

ç. $014,017,023,026,030,042,050,052,067$, 068, 074, 088, 090, 095, 097, 098. $\leftrightarrow$ çünki.

çünki (<F. çun+ki) 1. (Zaman yan cümlesinin başında) Ne zaman ki, -dığı zaman, -d1ğında, -1nca: 016, 045, 054. 2. (Sebep yan cümlesinin başında) Çünkü, zira, madem ki, dolayı, için, şunun için ki, şundan dolayı: 085. $\leftrightarrow$ çün.

\section{D}

dağla- (Özellikle yürek, iç, ciğer gibi kelimelerle) Büyük üzüntü vermek, acı ve 1st1rap çektirmek, yakmak.

yürekin d.- $\rightarrow$ yürek.

d.- d 1078

dahı Daha, bile, da/de.

d. 007,076 
damaḳ Ağız boşluğunun üst çeperi, damak.

d. $+1 \mathrm{~m} 056$

dapıy-Tabi olmak, hizmet etmek, bir işi yerine getirmek.

d. -015

dārü's-selām (< Ar. birleşik isim dārü's-selām) Cennet.

d. ol-Cennet olmak: 093.

datlu (Mecaz) Sevimli, hoş, güzel.

d. cān İnsana her şeyden daha tatlı gelen kendi canı, kendi varlığ1: 074, 083.

de- Demek, söylemek. $\leftrightarrow$ di-

d.- di 022

d.- ye 059

degin (Edat) Bir işin sona erdiği zamanı ve yeri gösterir, -e kadar, -e dek.

d. 056

$\operatorname{dem}(<$ F. dem) Zaman, çă̆g, vakit, an.

d. 013,036

deyiz Deniz.

d.+ dür 006

derd (<F. derd) Dert, sıkıntı, üzüntü, keder.

d.+ e 022

d.+ in 033

destān (< F. dāstān) Milletlerin eski çağlardaki din, fazilet ve millî kahramanlık maceralarını, başlarından geçenleri dile getiren büyük manzum hikâye, dâsitan, epope.

d.-ı şuhmā Şuhmâ'nın Hikâyesi: 001.

$\operatorname{devā}(<$ Ar. devāa) İlaç, çare, derman.

d. 022

d. + s1 033

di- Demek, söylemek. $\leftrightarrow$ de- d.- di 018, 049, 054, 095

d.- digüm 066

d.- rsem 020

d.- yim 030

d.- yü 053

dile- Dilemek, istemek, arzu etmek.

d.- di 047, 055

d.- ye 058

$\operatorname{din}(<\operatorname{Ar} . \operatorname{din})$ Din, inanç.

d. dönder- Dininden vazgeçip başka dine inanmak: 099.

d. 004,027

diyle- (Bir sese ya da söze) Kulak vermek.

d.- di 055

diril- (< déril-) Toplanmak.

d.- di 050

ditre- Titremek.

d.- di 029

dīvār (< F. dìvār) Duvar.

d.+ 1dir 003

dizil- Belirli bir düzene göre sıraya konmak, bir sıra teşkil etmek.

d.- diler 042

doğrı Gerçek, doğru. $\leftrightarrow$ doğru.

d. 002,030

doğru Gerçek, doğru. ↔ doğrı.

d. 001

doyur- İhtiyacını yeterince karşılamak, tatmin etmek.

șuyad. $\rightarrow$ șu.

d. -057

dön- Yüzünü çevirmek, dönmek, yönelmek, başını çevirip bakmak. 
d.- di 063, 092

dönder- Çevirmek, döndermek.

$\operatorname{din} d . \rightarrow$ dìn.

d.- ür 099

dört Dört sayısı.

d. 003

$\operatorname{du}^{`} \bar{a}\left(<\operatorname{Ar} . d u^{\prime}\left(\bar{a}^{\prime}\right)\right.$ Dua, Tanrı'ya yalvarış.

d. ḳl- Dua etmek: 017.

d. + lar 102

durur (Bildirme) -dır/-dir (dur- fiilinin hâl sigas1. 14. yüzyıldan sonra arkaizm ya da bir beytin boş yerini doldurmak için kullanilırd1).

d. 027,033

duy- İşitmek.

d.- $\operatorname{masin} 038$

dün Gece.

d.+-ile 100

dünyā (< Ar. dunyā) Dünya, yeryüzü.

d.+ ya gel-Doğmak: 084.

d. 002,006

düş- 1. Yıkılmak, yere düşmek: 075. 2. Anlamca kaynaşmış-kalıplaşmış birleşik filler yapar: 030, 064, 082.

ayru düş- $\rightarrow$ ayru.

sefer d. $_{\text {- } \rightarrow \text { sefer. }}$

muhkem d.- $\rightarrow$ muhkem.

d.- di 030

d.- eyim 064

d.- mişem 082

d.- üben 075

düş Rüya, düş.

d.+ de 088
E

eflāḥ (< Ar. eflāḥ "felah bulmuş, kurtuluşa ermiş") Köle, hizmetçi.

e. $045,049,050,053,062,074,076$

e.+ a 044

eg- (Boyun için) Eğmek, bükmek.

boyun $e^{-} \rightarrow$ boyun

e.- mek 085

eger (<F.gar/agar) (Edat) Eğer, şayet. $\leftrightarrow$ ger.

e. 076

ehl (< Ar. ehl) Halk, topluluk, bir yerin sakinleri.

e.+ i 058

elli Elli sayısı.

e.+ ye 059

emir (< Ar. amr) Emir, buyruk. $\leftrightarrow$ emr.

e. dapı- Emri yerine getirmek, emre tabi olmak: 015

emr (< Ar. amr) Emir, buyruk. $\leftrightarrow$ emir.

e. țut- Verilen emri yerine getirmek: 099.

e.+ i 080

e.+ idür 085

e.+ in 062, 099

e.+ ine $065,082,085$

er Erkek.

e. ü 'avrat Erkek ve kadın, herkes: 043.

esirge- Korumak, sakınmak.

e.- me 053

ev Ev, oturulan yer, mesken, hane.

e.+ e 018, 022, 023, 029, 032

e.+ inden 035

e.+ ine 034 
e.+ inin 003

ey (Seslenme ünlemi) Ey, hey, bre, be.

e. $027,032,035,038,046,048,056,060,063$, 066, 071, 081, 082, 083

eyit-Demek, söylemek. ↔ eyt-

e.- di 048

e.- diler 015

eyle- "Yapmak, etmek" anlamında yardımcı fiiller yapar. $\leftrightarrow$ iyle-

hoşnud e.- $\rightarrow$ hoşnud.

hatim e.- $\rightarrow$ hatim.

atalık e.- $\rightarrow$ atallk.

tamām e.- $\rightarrow$ tamām.

takdìr e.- $\rightarrow$ takdīr.

e.- di 091

e.- diler 087

e.- mişim 096

e.- yelüm 073

e.- yem 008

eyt-Demek, söylemek. $\leftrightarrow$ eyit-

e.- diler 051

e.- eyin 001

e.- ir 056

e.- ür 020, 025, 027, 030, 032, 033, 037, 038, 040, 044, 052, 058, 059, 060, 062, 063, 064, 065, 066, 069, 071, 072, 073, 076, 091, 092, 095, 096

F

feryād (< F. faryād) İmdat isteme, yardım dileme.

f. it- İmdat istemek, yardım dilemek: 055.

fi’l (< Ar. fi’l) İş, eylem, amel.

f.+ iyle 024 fülān (< Ar. fulān) Belirtilmesi gerekli görülmeyen isimlerin önüne getirilerek onları belirsiz şekilde niteler, herhangi biri.

f. 032

\section{G}

garḳ Suya batma.

$\dot{g}$. it- Suya batırmak: 006.

g. ol- Suya batmak: 007.

geç- 1. Hastalığı geçmek, iyileşmek: 021. 2. Aradan zaman geçmek: 026.

g.- er 026

g.- $\operatorname{esin} 021$

gel-1. (-den, -e) Varmak, ulaşmak, gelmek: 014, 026, 077. 2. Yaşamak, dünyaya gelmek: 012.

$$
\begin{aligned}
& \text { üşe g.- } \rightarrow \text { üş- } \\
& \text { dünyāya g.- } \rightarrow \text { dünyā. }
\end{aligned}
$$$$
\text { g.- di 014, 021, 029, 070, } 077
$$

g.- medi 012

g.- meseydi 084

g.- sün 060

g.- ür 026, 032

gemi Gemi.

g. 006

g.+ ye 007

ger (<F.gar/agar) (Edat) Eğer, şayet. $\leftrightarrow$ eger.

g. 008,025

gerek- Lazım olmak, gerekmek.

g. 037,085

getür- 1. (Daha uzak bir yerden) Bulunulan yere gelmesini sağlamak, gelmesine sebep olmak, iletmek, nakletmek: 028, 044. 2. Birleşik fiil yapar: 040 .

yerine g.- $\rightarrow$ yer. 
g. 044

g.- $\operatorname{dim} 028$

g.- em 040

gibi Gibi (Benzetme edatı).

g. 007

gir-Dışarıdan içeriye geçmek, içine dalmak, bir şeyin içine girmek.

g.- di 034

g.- en 006

g.- meyen 007

git- 1. Gitmek, varmak, ilerlemek: 002, 018, 023.

2. Ölmek: 083. 3. Birleşik fiiller yapar: 075.

$$
\begin{aligned}
& \text { uṣsl g.- } \rightarrow \text { us. } \\
& \text { g.- diler } 002 \\
& \text { g.- en (giden) } 083 \\
& \text { g.- er (gider) 023, } 075 \\
& \text { g.- erken (giderken) } 018
\end{aligned}
$$

giy- Elbise giymek, vücuduna geçirmek.

g.- miş 090

gizle- (Bir şeyi) Başkasına duyurmamak, saklamak.

g.- yem 025

gönder- Göndermek, yola koymak, yollamak.

g.- diler 086

göyül Gönül, kalp.

g.+ üm (göylüm) 080

gör- 1. Bakmak, görmek, gözle seçmek: 043, 060, 090. 2. Anlamak, idrak etmek, sezmek: 017, 023, 029.

g. $017,023,024,029,098$

g.- diler 043

g.- elüm 061 g.- eyim 063

g.- sün 060

g.- ür 088, 090

görgülü Davranışları toplumun görgü kurallarina uygun olan kimse.

g. 012

görün- Görünmek, ortaya çıkmak, belli olmak.

g.- ür 089

göz Göz, görme organı.

g.+ in 063

g.+ ümün 079

gözle- Gözetmek, önem vermek, riayet etmek.

g. 062

gușṣa (< Ar. ġușsa) Gam, keder, hüzün, tasa.

g. kayg்u ye- Üzülmek: 053.

güher (<F.gevher-guher) Mücevher.

g. 089

gül (< F. gul) Gül ağacının güzel kokulu ve pek çok çeşidi olan çiçeği.

g.+ leri 004

g.+ üm 081

gülzār (<F.gul-zār) Gül bahçesi.

g.+ Inuy 004

gün Gün (24 saatlik zaman dilimi).

g. 031,064

günāh (<F. gunāh) Günah, suç, hata.

g.+ indan 094

güneş Güneş.

g.+ çe 089

güzel Güzel, hoş.

g. ol-Güzel olmak, yakışmak: 090. 


\section{$\mathrm{H}$}

haber (< Ar. habar) Haber, bilgi, malumat, havadis.

h. ol- Haber verilmek: 069.

h. 009,030

had (< Ar. hadd) Şeriatın tayin ettiği ceza. hadd.

h. ur- Şeriat hükmünce suçluyu sopayla döverek cezalandirmak: 039, 037.

ḥadd (< Ar. ḩadd) Şeriatın tayin ettiği ceza. had.

h. ur- Şeriat hükmünce suçluyu sopayla döverek cezalandirmak: 040, 044.

h. + in 044,076

h.+ ini 040

hak (< Ar. hakk) Hak, Allah, Tanrı. ↔ haḳ̣.

h. 065,094

hạk (< Ar. hakk ) Hak, Allah, Tanrı. $\leftrightarrow$ hạa.

cānı ḥ. vir- $\rightarrow$ cān.

h.+ a $074,086,100$

h. + 1y 085

hạal (< Ar. ḥāl) Durum, vaziyet.

h.+ de mi 072

h. $+\operatorname{im} 060$

h.+ ini 052, 098

halāyık (< Ar. halā’ik “yaratıklar, insanlar”dan) Esir edilmiş veya satın alınmış kız, kadın.

h. 017

halk (< Ar. halk) Halk, insanlar, ahali, toplum, kalabalı.

h. $014,070,075$

h.+ a 037

h. +1042 h.+ 1 1y 078

harāb (< Ar. harāb) Kötü durumda, bitik, perişan.

h. ol- Kötü durumda olmak, perişan olmak: 034

ḥasret (< Ar. hasrat) Özlem, özleme, özleyiş.

h. kal- Sevdiği birine kavuşamamak, özlemek: 061

hastelik (< F. hasta + T. -lik) Hastalık.

h.+ ten 021

hasūù (< Ar. ḩasūd) Haset, kıskanç.

h. 018

hatim (< Ar. hatm) Bitirme, sona erdirme, tamamlama.

h. eyle- Tamamlamak: 087.

hayr (< Ar. hayr) Hayır, iyilik.

h. 101

ḥayrān (< Ar. ḥayrān) Çok beğenen, bayılan.

h. kal- Hayran olmak, beğenmek: 090.

h. ol- Çok beğenmek: 013

hazāa (< Ar. hażā) İşte, bu, şu.

h. 002

hem (< F. ham) Kullanıldı̆̆1 cümleye "üstelik, bir de, şu da var ki, zaten" manaları katarak anlamı kuvvetlendirir.

h. $003,010,037,089,090,097$

hep (<F. ham) Hep, bütün, hepsi.

h. 022

her (< F. har) Tekil kelimelerin önüne getirilir ve o kelime için verilen hükmün aynı cinsten olan şeylerin hepsi için teker teker geçerli olduğunu gösterir, -nin hepsi, bütün, cümle.

h. $013,066,102$ 
hergiz (< F. hargiz) Asla, katiyen, hiçbir zaman.

h. 012

hiç (< F. hìç) Asla, katiyen (Olumsuz ve soru cümlelerinde anlamı kuvvetlendirir.).

h. 044,053

ḥikāyet (< Ar. hikāya) Hikâye.

h. 001

hoş (< F. hoş) İyi, güzel.

h. 096

hoşnūd (<F. hoşnūd) Bir kimseden veya hâlden memnun olma durumu, razı.

h. eyle- Memnun etmek, gönlünü hoş etmek, razi etmek: 091.

h. ol- Memnun olmak, gönlü hoş olmak, razı olmak: 093.

hūūb (<F. hūūb) Güzel.

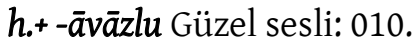

h. 010

hulk (< Ar. hulk) Yaratılış, tabiat, huy, karakter.

h. +1010

ḥükm (< Ar. ḥukm) Emir, buyruk.

h.+ idür 079

hülle (< Ar. hulla) Cennet elbisesi.

h. 090

$\dot{\mathbf{I}}$

i- Ek fiil, isim soylu kelimelerin cümlede yüklem olarak kullanılmasını sağlar. Çekimli fiilleri de birleşik zamanlı olarak kullanılmasını sağlar. "idi, imiş, ise ve iken" şekilleri vardır.

i.- di 010, 011, 071

i.- $\operatorname{dim} 032$

i.- dün 031 i.- $\operatorname{sen} 025$

iç İç, iç taraf, içerisi.

i.+ inde 001, 002, 009, 024, 035

i.+ ine 041

iç- (Su vb.) İçmek.

i. 022

i.- di 023

i.- $\operatorname{dim} 034$

i.- $\operatorname{esin} 021$

i.- $\operatorname{mez} 025$

içim Bir defada içilecek miktar.

i. 057

içün (Edat) İçin, maksadıyla, amacıyla.

i. 002,098

iki İki sayısı.

i. 047

ile (Edat) İsimlere gelerek "ile, birlikte, araç, vasita vb. anlamlarda zarf yapar.

i. $028,036,088,101$

ilet-Götürmek, ulaştırmak, eriştirmek.

i.- di 022, 041

illā (< Ar. illā) Fakat, lakin, ancak.

i. $036,058,068$

imdi Şimdi, şu an.

i. 009

inle- Acı ve üzüntü ile ağlayıp sızlanmak.

i. 100

i.- di 047,072

ir- Belli bir yere, bir noktaya yetişmek, erişmek.

i.- icek 055

i.- sün 059, 065, 069 
irgür- Ulaştırmak, eriştirmek.

i.- di 050

is Sahip.

i.+ si 027

iş İş, amel, hareket, davranış.

i.+ den 036

i. + i 062

i.+ ine 065

i.+ lerinüz 101

işbu Bu, işte bu.

i. 008,009

işit- Dinlemek, işitmek.

i. 002,009

i.- di 029

i.- diler 067

i.- elüm 015

i.- me 059

i.- $\operatorname{mez} 068$

işitil- Duyulmak, işitilmek.

i.- medi 012

işle- Yapmak, etmek.

i.- yüz 066

it- (1) “Yapmak, etmek, kılmak” anlamında birleşik fiiller yapan yardımcı fiil.

feryād $i . \rightarrow$ feryād.

garki. $\rightarrow$ gark.

șaburi. $\rightarrow$ șabur.

șabır i.- $i$ vir- $\rightarrow$ șabır.

terki. $\rightarrow$ terk.

i.- di 055

i.- diler 002

i.- elüm 068 i.- er 072

i.- meye 006

it- (2) Demek, söylemek.

i. 030

i.- gil 031

iyle- "Yapmak, etmek" anlamında yardımcı fiiller yapar. $\leftrightarrow$ eyle-

teziki. $\rightarrow$ tezik.

\section{K}

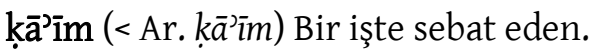

k. ol- Kararından dönmemek, yaptığı işi sonuna kadar devam ettirmek: 065.

kal-1. (Bir yerde) Olmak, bulunmak: 007. 2. Birleşik fiil yapar: 061, 090.

hasret $k \rightarrow$ hasret.

hayrān k. $\rightarrow$ hayrān.

k.- 1 sar 007

k.- madan 061

k.- $\operatorname{ur} 090$

ḳamı Bütün, hep, hepsi, tamamı. $\rightarrow$ ḳamu.

k.+ $\sin 1008$

ḳamu Bütün, hep, hepsi, tamamı. $\rightarrow$ ḳamı.

k. 014,042

ḳanda Nerede.

k. 031

kanı Hani, nerede.

k. 060

kavm (< Ar. kavm) Kavim, halk, insanlar.

$n \bar{u} h \underline{h} k_{.}+i \rightarrow n \bar{u} h$.

k.+ i 007, 055

ḳayg்u Üzüntü, dert, keder, endișe, tasa.

$\dot{g} u s ̦ s a k . y e-\rightarrow \dot{g} u s s a$. 
k. 053

ḳayır- Üzülmek, tasalanmak, endişe etmek.

k.- mağll 020

kebīr (< Ar. kebir) Yaşlı.

yigit ü $k . \rightarrow$ yigit.

k. 016

kefin (< Ar. kefen) Kefen.

k.+ e 086

kerīm (< Ar. kerim) Allah.

k. 046

keşke (< F. kāşki) Keşke, ne olurdu anlamında dileklerde kullanılan bağlaç.

k. 084

ḳ1- "Etmek, k1lmak, yapmak" anlamında birleşik fiiller yapan yardımcı fiil.

$\bar{a} h k_{.} \rightarrow \bar{a} h$.

āşikāre k. $\rightarrow$ āşikāre.

'avrata k. dim 036

$d u^{c} \bar{a} k_{.} \rightarrow d u^{c} \bar{a}$.

issi $k_{.} \rightarrow i s s i$.

muhabbet $k_{.} \rightarrow$ muhabbet.

namāzın k. $\rightarrow$ namāz.

nek. $\rightarrow$ ne.

tövbe $k$. $\rightarrow$ tövbe.

$z i n \bar{a} k_{.} \rightarrow z i n \bar{a}$.

k.- $d_{1} 028,048$

k.- dilar 005, 087

k.- $\operatorname{dim} 036$

k..- dındi 039

k.- ma 044

k.- up 072

k.- ur 017, 024, 098 ḳılıç Kılıç.

k.+ $1 \mathrm{nn} 005$

kııḳ Kırk sayısı.

k.+ a 056

ki Ki bağlama edatı.

$t \bar{a} k i \rightarrow t \bar{a}$.

k. $029,045,059,102$

kiçi Küçük.

ulu $k_{0} \rightarrow$ ulu.

k. 043

kim Kim, ki (bağlama edatı).

k. $014,019,030,031,051,054,057,078,091$, 092, 094, 098

kimi Kimi, bazısı.

k. 099

kimse Kimse, herhangi biri, hiç kimse.

k. $038,058,072$,

ko- Bırakmak.

k. 062

kork- Korkmak, ürkmek, endişe etmek.

k.- aram 064

kurān (< Ar. kur'ān) Kur'ân-1 Kerim.

k. $013,015,031$

k.+ 1087

kuru- Kurumak, 1slaklığını kaybetmek.

k.- d 1056

L

lāyık (<Ar. lā’’ị) Layık, uygun, yaraşır.

1. 041

leşker (< F. leşker) Asker.

1.+ inüy 027 
ma'şūḳ (<Ar. ma'ş̧ūk) Aşık olunan kimse, sevgili (Metinde ilahî sevgili Allah anlamındadir.).

m. 098

mescid (<Ar. mescid) Mescit, küçük cami.

m.+ e 014, 031

meydān (< Ar. meydān) Meydan, alan, saha; geniş, düz ve açık alan.

m. 041

m.+ a 042

minnet (< Ar. minnet) Yapılan bir iyiliğe karş1 teşekkür etme, şükür, hamdetme.

m. 096

muhabbet (< Ar. muhabbet) Sevgi.

m. ḳl- Sevgi göstermek, merhamet etmek: 044.

muḥkem (< Ar. muḥkem) İyice, adamakıllı, sağlamca.

m. düş- Bir şeye bağlı kalmak: 082.

mușțafā (< Ar. mușțafā) Hz. Muhammed.

m. $004,11,040,088$

m.+ dan 12

m.+ niy 103

m.+ ya 101

mühlet (< Ar. muhlet) Mühlet, vade, süre, mehil.

m. 047,055

müstecāb (< Ar. mustecāb) Kabul edilen.

m. ol- Kabul olmak: 102.

$\mathbf{N}$

n'eyle- Ne yapmak, ne etmek.

n.- yelüm 073, 080 n'it- Ne etmek, ne yapmak.

n.- elüm (n’idelüm) 068

n.- er (n’ider) 023, 029

n.- mek 085

namāz (<F. nemāz) Namaz.

n. ḳll- Namaz kılmak: 087.

n.+ 1 in 087

ne Ne.

n. ḳl- Ne yapmak: 024, 098.

n. var Ne olur, ne çıkar: 076.

n. $017,020,059,071,076,098$

n.+ ler 002

nefeslü (< Ar. nefes + T. -lü) Nefesli.

n. 081

ner (<F. ner) Erkek.

şir-ü n. $\rightarrow$ şir.

n. 077

nice Nasil.

n. 002

n.+ dür 009

niçün Niçin

n. 018,063

nite Nasil.

n. 033,094

nūr (< Ar. nūr) Işık, aydınlık, parlaklık, nur.

n.+ dan 089, 090

n.+ 1079

0

og̉ul Erkek çocuk.

o. 030

o.+ an (og̉lan) 026, 027, 097 
o.+ 1 (og $\left.\operatorname{ll}_{1}\right) 010$

o.+ uma (og̉luma) 096

o.+ un (og̉lun) 077, 099

o.+ uy (og̉lun) 027

og̉lan Erkek çocuk.

o.+ 1 (og̉lanı) 028

o.+ um (og̉lanum) 071

oḳu- Bir metni seslendirmek, yüksek sesle k1raat etmek.

o. 015

o.- $d_{1} 016$

o.- duy 031

o.- $\operatorname{rd}_{1} 013$

ol o (işaret sıfatı).

o. $007,018,020,022,031,032,035,036,061$, 069, 077

ol- 1. Olmak, bulunmak, meydana gelmek: 084.

2. "Olmak, bulunmak, meydana gelmek" anlamında yardımcı fiil: 019, 034, 097.

bir yll o. $\rightarrow$ bir.

dārü's-selām o. $\rightarrow$ dārü's-selām.

gark. o. $\rightarrow$ gark.

güzel o. $\rightarrow$ güzel.

haber $0 . \rightarrow$ haber.

harāb o. $\rightarrow$ harāb.

ḥayrān o. $\rightarrow$ ḥayrān.

hoşnūd o. $\rightarrow$ hoşnūd.

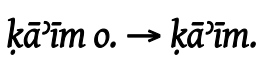

müstecāb o. $\rightarrow$ müstecāb.

sekrān o. $\rightarrow$ sekrān.

şākir o. $\rightarrow$ şākir.

tamām 0. $\rightarrow$ tamām.

vaḳı'ät o. $\rightarrow$ vaḳı'ät. o.- a 102

o.- d 1019

o.- dum 034

o.- 1sar 007

o.- masaydi 084

o.- mış 097

o.- mışım 093

o.- sun $069,093,101$

o.- uban 023

o.- ur 017,090

o.- $\operatorname{urd}_{1} 013$

on On sayısı.

o. 076

o.+ a 050

otuz Otuz sayıs1.

o.+ a 055

\section{ö}

öl- Ölmek.

ö.- dise 076

ö.- e 053

ö.- em 057

ö.- meden 061

ö.- ürem 060

öldür- Öldürmek.

ö. 038

ö.- ür isā 099

\section{P}

pādişāh (< F. pād-şah) (Hüküm sahibi, hükmeden) Allah.

p. 048

pāre (<F. pāre) Parça.

p.+ si 079, 083 


\section{$\mathbf{R}$}

rahịm (< Ar. raḥim) Allah.

r. 046

rāḥmet (< Ar. rāḥmet) Allah'ın kullarına acıması, günahlarını bağışlaması; Allah'ın merhameti.

r.+ den 019

resūl (< Ar. resūl) Peygamber, Hz. Muhammed.

r. 091,097

reyḥān (< Ar. reyḥ̄an) Fesleğen.

r.+ $1 \mathrm{~m} 081$

rūḥ (< Ar. rūḥ) İnsan ve hayvanda vücudu canlı kılan, bilen, duyan ve idrak eden hayat gücü, hayat cevheri, can.

r.+ ina 103

\section{S}

șabır (< Ar. șabr) Sabır, dayanma gücü, tahammül.

ș. it- Sabretmek, dayanmak: 073.

s. iti vir- Sabır edivermek, katlanmak, tahammül etmek: 051.

șağıl- Hızla gitmek.

ș.- d1 014

șaḥābe (< Ar. șaḥābe) Hz. Muhammed'in sohbetinde bulunmuş, onu görmüş olanlar; sahabeler.

ș.+ ler 011

șal- Bırakmak.

ș.- dilar 005

șalavāt (< Ar. șalavāt) Hz. Muhammed ve onun soyundan gelenlere sayg bildirmek için okunan dua.

ș. vir- Dua okumak: 101, 103.

saya Sana. s. $008,021,037,048,064,071,084$

șar- (Kefen vb. için) Sarmak, kaplamak, örtmek.

ș.- dilar 086

șarı Sarı renk.

ș. 018,033

s..+ yım 019

șataş- Musallat olmak, rahatsız edici davranışlarda bulunmak.

s.- di 018

sefer (< Ar. sefer) Yolculuk.

s. düş- Yolculuğa çıkmak: 030.

sekrān (< Ar. sekrān) Sarhoș.

s. ol-Sarhoş olmak: 023.

seksen Seksen sayısı.

s.+ e 069

sen Sen (2. tekil şahıs zamiri). $\leftrightarrow$ sin.

s. $020,031,059,073,100$

s.+ den 086

s.+ inçün 068

s.+ in 027

sev- Sevmek, sevgi duymak.

s.- er 011

ș1- (Bir kimseyi) Darıltmak, kırmak, gücendirmek.

ș.- mağil 020

șığın- Kendisini koruması için Allah'a sığınmak, Allah'tan yardım istemek.

s..- dim 048

$\sin$ Sen (2. tekiş şahıs zamiri). $\leftrightarrow$ sen.

s. 092 döndi

șol- Solmak, rengi atmak, benzi sararmak.

s..- di 029 
șoyra Sonra.

Ș. 012

șor- Sormak, sual etmek, soru sorarak bilgi istemek.

ș.- mayasız 052

șoy- (Birinin) Elbisesini çıkarmak.

S.- d 1045

söyle- Demek, söylemek.

S. 092

s.- yem 008

söz Söz.

S. 102

s.+ den 009

s.+ i 025, 037, 067, 095

s. + in 008

s.+ ümi 020

șu Su.

ș.+ ya doyur- Su ihtiyacinı gidermek, doyunca su içirmek: 057.

S.. 057,058

Ș.+ y1 023

ș.+ y1m 022

șuç Suç, günah, kabahat.

s..+ 1na 041

șuṣa- Su içme ihtiyacı olmak.

s..- ya 058

süci Şarap.

s. 024,025

\$̧

şākir (< Ar. şākir) Şükredici kimse, şükreden.

Ş. ol- 097

şarāb (< Ar. şerāb) Şarap, alkollü içki.
Ş. 034

şer ${ }^{c}(<$ Ar. şerc) Allah'ın emri, dinin kuralları, şeriat. $\leftrightarrow$ şeric $^{c}$

Ş.+ ini 040

şerbet (< Ar. şerbet) Tatlı içecek.

Ş. 021

şeric (< Ar. şerc) Allah'ın emri, dinin kuralları, şeriat. $\leftrightarrow$ şerc .

Ş. $001,002,005,009$

Ş.+ i 008

ş.+ in 005

şerī'at (< Ar. şerī'at) Allah'ın emri, dinin kuralları, şeriat.

Ş. 006

şeş- Çözmek.

ş.- di 077

şimdi Şimdi, şu an.

\$̧. 038

şīr (< F. şir) Arslan.

ş.-ü ner Erkek arslan: 077.

şol Şu.

Ş. 031,036

şöyle Öyle, o şekilde, onun gibi.

Ş. 078, 094

ş.+ dür 095

şükür (< Ar. şukr) Verdiği nimetler için Allah'a duyulan minneti dile getirme, şükür, şükran.

Ş. $049,096,097$

\section{$\mathrm{T}$}

tā (<F. tā) Ta, kadar, dek, değin.

tā ki Sonunda, yeter ki: 102.

t. 041 
tāc (< Ar. tāc) Taç.

t. ur- Taç takmak: 089.

taḳdīr (< Ar. taḳdī) Bir şeyin değerini belirleme, ona değer biçme.

t. eyle- Değerini belirtmek: 008.

tamām (< Ar. tamām) Tam, bütün, eksiksiz.

t. eyle- Tam ve eksiksiz yapmak, tam olarak yerine getirmek: 073 .

t. ol- Bitmek, sona ermek, tamamlanmak: 101.

t. $049,074,077,087,093$

țamu (< Soğd. tamw) Cehennem.

t. 058

tayrı Tanrı, Yaradan, Allah.

t. $040,044,073,079,080$

ten (<F. ten) Vücut, beden.

t. + in 045

terk Birakmak.

t. it-Birakmak, vazgeçmek: 068.

tevzik (<?) Çabuk, hızlı.

t. iyle- Çabuk olmak, acele etmek: 100.

tọg- Doğmak, dünyaya gelmek.

t.- $\operatorname{ar} 026$

țoksan Doksan sayısı.

t. 074

țokun- Dokunmak, değmek, temas etmek.

t.. $-d_{1} 048$

țokuz Dokuz sayısı.

t. 026

tol- İyileşmek.

t.- a 021

ton Elbise. t.+ $\ln 045$

tövbe (< Ar. tevbe) İşlediği günahtan pişmanlık duyup bir daha yapmamaya söz verme.

t. ḳıl- İşlemiş olduğu bir günahı bir daha yapmamaya söz vermek: 036.

țur- (Bir yerde) Durmak, kalmak, beklemek, bulunmak.

t.- $\operatorname{ur} 088$

țurrā (< Ar. turre ?) Kamçı, kırbaç. ↔ țurrā’)

t. $045,047,048,049,054,055,056,059,065$, 069

țurrā’(< Ar. turre ? Kökü kesin olarak belli değildir.) Kamçı, kırbaç. ↔ țurrā.

t. $044,050,053,077$

țut- (Bir şeyi) Yapmak, yerine getirmek.

emrin t. $\rightarrow$ emr.

t.-- up 099

\section{U}

uçmaḳ (< Soğd. uştmah్) Cennet.

u. 093

uğra- Karşılaşmak, rastlamak, tesadüf etmek.

u.- $\operatorname{dim} 032,035$

ulu Büyük, yaşlı.

u. kiçi Büyük küçük: 043.

ur- Vurmak.

had u. $\rightarrow$ ḥad.

$t \bar{a} c u_{0} \rightarrow t \bar{a} c$.

u. $053,062,076$

u.- $\operatorname{am} 040$

u.- di 045, 049, 074, 077, 078

u.- 1cak 047

u.- mak 037

u.- ur 089 
uṣ Akıl.

u.+ șl git- Bilincini yitirmek, kendinden geçmek: 075.

uş İşte, şimdi.

u. 028

utan- Onur kırıcı bir durum nedeniyle ezici bir küçüklük, bir alçalma duygusu içinde bulunmak; utanç duymak; hicap etmek; mahçup olmak.

u.- 1 rim 038

u.- mayup 039

u.- ursin 039

uyan- Uykudan uyanmak.

u.- di 095

uyḳu Uyku.

u.+ ya var- Uyumak: 088.

$\ddot{U}$

$\ddot{u}(<\mathrm{F} . u<$ Ar. ve) Ve bağlacının nazımda sessiz harflerden sonraki okunuşu.

er ü. 'avrat $\rightarrow$ er.

yigit ü. kebir $\rightarrow$ yigit.

ü. 016, 043

üç Üç sayısı.

ü. 048

ün Ses.

ü.+ i 011

ü.+ üne 011

ünli Ün sahibi, meşhur, namlı.

ü. 012

üst Üst, üzeri; bir kimsenin kendisi, şahsı.

ü.+ ine 070,075

üş- Hep birden bir yerde toplanmak, yığılmak, üstüne üşüşmek.

ü.- diler 042, 043 ü.- e geldi 014

ü.- miş 070

ü.- üben 075

\section{V}

vaḳı ${ }^{\prime a}\left(<A r . \operatorname{vaklı}_{1}{ }^{c} a\right)$ Olmuş olan şey, olay. vaḳı̄āt.

v. 071

v.+ lar 084

vaḳı'āt (< Ar. vaḳı'āt) Başa gelen, baştan geçen olaylar. $\leftrightarrow$ vaḳı́a.

v. ol- Başa gelmek: 017.

var-1. (Bir yere) Gitmek, varmak, ulaşmak: 001. 2. Birleşik fiil yapar: 088.

uykuya v. $\rightarrow$ uyḳu.

V.- di 088

v.- anlara 001

var Var olan, bulunan.

nev. $\rightarrow$ ne.

v. 010,033

v.+ a 076

ve's-selām (< Ar. ve's-selām) (Ünlem) İşte o kadar, son söz budur, artık bitti; barış, esenlik için.

v. $049,087,101$

vir- 1. (Bir şeyi bir kimseye) Vermek, ulaştırmak, iletmek: 021, 034, 058. 2. Göndermek: 101, 103. 3. Birleşik fiiller yapar: $041,074,101$

$c \bar{a} n v . \rightarrow c \bar{a} n$.

cezā $v . \rightarrow$ cezā.

datlu cānı hakka v. $\rightarrow$ datlu.

sabur iti v. $\rightarrow$ șabur.

șalavāt v. $\rightarrow$ șalavāt.

v.- di 034, 074 
V.- e 041

V.- eyim 021

V.- meye 058

V.- sünler 057

v.- ün 028

v.- ür 099

$\mathbf{Y}$

yā (< Ar. yā) Ey (seslenme bildiren ünlem). y. 030, 051, 053, 062, 072, 076, 091, 092

yahūd (< Ar. yahūd) Yahudi. $\leftrightarrow$ yahūdī.

y. $018,020,035$

y.+ a 032

yahūdī (<Ar. yahūìi) Yahudi. $\leftrightarrow$ yahūd.

y. 022

yalın Çıplak, üryan.

y. 070

yalvar- 1. Birinden bir şey istemek, dilemek: 047, 051. 2. Allah'tan bir dilekte bulunmak, niyaz etmek: 100.

y. 100

y.- d 047

y.- uban 051

yan Yan, taraf, etraf. $\leftrightarrow$ yan.

y.+ 1na 050

yay Yan, taraf, etraf. $\leftrightarrow$ yan.

y.+ a 086

yar- Derin yara açmak.

y.- d 045

yara $(<\mathrm{F} \cdot y \bar{a} r+\bar{a})$ Arkadaş, dost, yardımcı.

y. 005

yāran (<F. yārānn) Dostlar, arkadaşlar.

y.+ lar 050, 067

$$
\begin{array}{r}
\text { y.+ lara } 001 \\
\text { y.+ larım } 066 \\
\text { yarınḳı Yarınki. }
\end{array}
$$

y. 064

yazı̣ Günah.

y.+ dan 094

ye- Hoşa gitmeyecek bir duruma uğramak, maruz kalmak.

$$
\text { gușṣa ḳayǵu y. } \rightarrow \dot{g} u s s a \text {. }
$$

y.- di 054

y.- me 053

yedi Yedi sayısı.

y. 093

yemiş Meyve.

y.+ i 080

yer Önem, değer.

y.+ ine getür- İstenileni, gerekeni yapmak; ifa etmek: 040.

yet-Bitmek, tamamlanmak.

$$
\text { y.- er 051, } 076
$$

y1l Y1l, sene.

bir y.ol- $\rightarrow$ bir.

у. 019

yigirmi Yirmi sayısı.

y. 054

yigit Genç erkek, delikanlı.

y. ü kebīr Genç yaşlı: 016.

yigitlik Gençlik.

y.+ de 083

yine Yine, tekrar, bir daha.

y. 014, 036, 039

yitmiş Yetmiş sayısı. 


$$
\text { y.+ e } 065
$$

yoḳ Bulunmayan, mevcut olmayan.

$$
\text { y.+ dur } 079
$$

yol 1. Yol, üzerinden geçilen yer: 024, 032. 2. Bir şeye ulaşmak için takip edilen seyir: 095.

$$
\begin{aligned}
& y .+ \text { a } 001 \\
& y .+ \text { da 024, } 032 \\
& y .+1095
\end{aligned}
$$

yörü- (Bir eşya için) Yürümek, hareket etmek.

$$
\text { y.- di } 056
$$

yu- Ylkamak.

$$
\text { y.- dilar } 086
$$

yürek Kalp, yürek; gönül.

y.+ in daġla- Yüreğini dağlamak, çok acı vermek: 078.

y.+ im 054

yüz (1) Yüz, çehre, surat.

y.+ i 089

y.+ ine 078

y.+ üy 063

yüz (2) Yüz sayısı.

y.+ e 077

\section{Z}

ża'îf (< Ar. $\left.\dot{z} a^{c}{ }^{\top} \mathfrak{f}\right)$ Zayıf, güçsüz, kuvvetsiz.

ż. 069

zār (< F. zār) Ağlayış, inleme. ↔ zārı, zārī.

$z \bar{a} r ı$ z. $\rightarrow z \bar{a} r ı$.

z. 071

zārı (< F. zārī) Ağlama, sızlama, inleme. $\leftrightarrow$ zār, zārī.

z. zār Hüngür hüngür ağlamak: 016. zārī (< F. zārī) Ağlama, sızlama, inleme. ↔ zār, zārı.

z. ḳll- Ağlayıp inlemek, feryat etmek: 072. zinā (< Ar. zināa) Evlilik dışı cinsel ilişki, zina.

z. ḳıl-Zina etmek, evlilik dışı cinsel ilişkiye girmek: 028, 036, 039.

\subsection{Kişi ve Yer Adları Dizini}

Aḳsarāylu cisā (< k.a.) Aksaraylı İsa. Hikâyenin anlatanı ve yazarı.

a. 100

'Alī (< k.a.) Hz. Ali. Hz. Muhammed'in Amcası Ebu Talip'in oğlu, dördüncü İslam halifesi.

'a. 003, 088, 090, 091, 092, 095

'a.+ ye 091

Ebū Bekir (< k.a.) İslam dininde ilk dört halifeden birincisi. Hz. Ebu Bekir.

e. 003

Nūḩ (<k.a.) Nûh peygamber.

n. kavmi Nûh peygamberin gönderildiği topluluk, halk: 007.

Oșmān (< k.a.) Hz. Osman. İlk dört halifeden üçüncüsüdür.

o. 003

'Ömer (<k.a.) Hz. Ömer. İlk dört halifeden ikincisidir.

'ö. 003, 009, 029, 030, 037, 040, 044, 051, 052, 058, 059,062, 064, 065, 069, 072, 073, 076, 077, 084, 091, 095, 96

'ö.+ e 026, 047

Şuhmā (< k.a.) Hikâyede Hz. Ömer'in oğludur. Hikâyede olaylar onun başından geçmektedir.

destān-l ş. $\rightarrow$ destān.

ş. $010,016,019,023,028,045,046,052,054$, 059, 060, 070, 074, 088, 092 
ş.+ ya 015, 017, 051

ş.+ y1 022, 041, 043

\subsection{Arapça İbareler Dizini}

allāhu āclem bi'ṣ-ṣavāb (< Ar. ibare) "Doğrusunu en iyi Allah bilir."

a. 102

el-ḥamdülillāh (< Ar. el-ḥamdu lillāh) Allah'a şükürler olsun, hamdolsun.

e. 049

fā'ilātün fācilātün fā'ilāt (< Ar. aruz ölçüsü) Aruz ölçüsünün Remel bahrinin kalıplarındandır. Türk edebiyatında en çok kullanılan kalıplardandır. 11'li hece ölçüsüne yakın olmasından dolayı kıssahânların en çok tercih ettiği kalıptır. Pek çok mesnevi bu kalıpla yazılmıştır.

f. 103

\section{4. Çekim Ekleri Dizini}

$+a$

'avrat+a, eflāh+a, hakkk+a, halk+a, kırk+a, meydan+a, on+a, otuz+a, yahūd+a, yay+a, yol+a

$-a$

ol-a, țol-a, var-a

-alım

çal-alım

-am

ur-am

$\tan$

og̉ul+an

-anlara

var-anlara

-ar -aram

kork-aram

+çe

güneş+çe

$+\mathrm{da}$

cihan+da, yol+da

+ dan

nur+dan, yazık+dan

+de

ben+de, düş+de, yigitlik+de

+den

ben+den, iş+den, rāḥmet+den

sen+den, söz+den

+ de mi

hāal+de mi

$-\mathrm{d} \mathbf{1}$

dağla- $\mathrm{d}_{1}, \mathrm{k}_{1} l-\mathrm{d}_{1}, \quad$ ol- $\mathrm{d}_{1}$, var- $\mathrm{d}_{1}, \quad a c 1-\mathrm{d}_{1}$, aǵla-d1, arıt-d1, ḳuru-dı, oḳu-dı, șaǵıl$d_{1}$, șataş-d1, șol-d1, șoy-d1, țoḳun-d1, ur$d_{1}$, uyan- $d_{1}$, yalvar- $d_{1}$, yar- $d_{1}$

-dilar

ḳıl-dılar, aç-dılar, ag̉la-dılar, ag̉laş-dılar, șal-dılar, șar-dılar, yu-dılar

$-\operatorname{dim}$

ḳıl-dım, șı̇̉ın-dım, uğra-dım, çık-dım

- dindı

ḳl-dındı

$-\mathrm{di}$

al-d1, düş-di, eyle-di, gel-di, it-di, virdi, de-di, di-di, dile-di, diple-di, diril-di, ditre-di, dön-di, eyit-di, gel-di, gir-di, iç-di, i-di, ilet-di, inle-di, irgür-di, işitdi, şeş-di, vir-di, ye-di, yörü-di

-digüm

di-digüm

-diler

togigar 
eyle-diler, dizil-diler, eyt-diler, git-diler, gönder-diler, gör-diler, işit-diler, it-diler, üş-diler

$-\operatorname{dim}$

getür-dim, iç-dim, i-dim

-dise

öl-dise

-dum

ol-dum

-duy

oku-dun

+ dur

bu+dur

yoḳ+dur

-düy

i-düy

+dür

böyle+dür, deniz+dür, nice+dür, şöyle+dür

$+\mathrm{e}$

derd+e, ev+e, kefin+e, mescid+e, cömer+e, seksen+e, yitmiş+e

$-e$

vir-e, bil-e, öl-e, üş-e

-elüm

it-elüm, gör-elüm, işit-elüm, n’it-elüm

-em

getür-em, öl-em

-en

gir-en, git-en

-er

git-er, geç-er, it-er, n'it-er, sev-er, yet-

e

-erken

git-erken

+esin iç+esin

-esin

geç-esin

-eyim

düş-eyim, gör-eyim, vir-eyim

-eyin

eyt-eyin

-gil

it-gil

$+1$

cān+1, ad+1, altmış+1, cān+1, halḳ̣+1, hulk+1, kuran+1, nūr+1, og̉ul+1, og̉ulan+1 yol+1

-1cak

ur-1cak

$+1 \mathrm{~d} ı \mathrm{r}$

dīvār+1dır

$+1 \mathrm{~m}$

bāg்+1m, bag்ır+1m, cān+1m, damaḳ+1m

reyhān+1m

+1ma

cān+1ma

$+1 \mathrm{miz}$

cān+1mız

$+\ln \quad-3-$

buyruk+1n, namaz+1n, țon+1n

+1na

āvāz+ına, rūḥ+1na, șuç+1na, yan+1na

+indan

günāh+1ndan

$+\ln 1$

baġır+1nı, ḳllıç+1nı

$+\ln 1 \mathrm{y}$

baǵ+1nıy

+ +nuy 
gülzār+1nuy

$-1 y$

dap-1y

$+10$

hakkk+1n

halk+1n

-1 rim

utan-ırım

-1 sar

ol-1sar, kal-1sar

$+\mathbf{i}$

kavm+i, ādem+i, ahvāll+i, ben+i, biz+i, ehl+i, emr+i, iş+i, kavm+i, ön+i, söz+i, şeri' $+i$, yemiş+i, yüz+i

$-\mathbf{i}$

it-i

-icek

ir-icek

+idür

emr+idür, hükm+idür

$+\mathrm{im}$

ben+im, ciger+im, hāāl+im, yürek+im

+in

(āyāl+in, emr+in, hạdd+in, söz+in, ten+in, yürek+in

+inçün

sen+inçün

+inde

iç+inde

+inden

ev+inden

+ine

emr+ine, ev+ine, iç+ine, iş+ine, üst+ine yer+ine, yüz+ine

+ini

hadd+ini, hāal+ini, șer+ini +inin

ev+inin

+inüy

leşker+inüy

+ in

beniz+iy, beyiz+iy, derd+iy, göz+iy, sen+ì, şericin

+ịüz

bir+inüz

-ir

eyt-ir

+iyle

fi'l+iyle

+ lar

‘āşı yāran+lar

+lara

yāran+lara

+lardur

bu+lardur

+larım

yāran+larım

+larını

baş+larını

+ler

șahāàbe+ler

+leri

bülbül+leri, gül+leri

$+m$

bākçe+m, ana+m

$-\mathrm{ma}$

ḳ1-ma

$+\mathrm{ma}$

ata+ma

-madan 


$$
\text { kal-madan }
$$

-magil

kayır-maġıl, ṣı-mag்ıl

-mak

$$
\text { ur-mak }
$$

-mam

buluş-mam

-masayd 1

ol-masayd 1

-masin

duy-masin

-mayasız

șor-mayasız

-mayup

utan-mayup

+mdan

ata+mdan

- me

ye-me, esirge-me, işit-me

-meden

öl-meden

-medi

gel-medi, işitil-medi

-medim

bil-medim

-mek

bildür-mek, eg-mek, n'it-mek

-meseydi

gel-meseydi

-meye

it-meye, vir-meye

-meyen

gir-meyen

+ mez

iç+mez

-mez işit-mez

- mış

ol-mış

-mişım

ol-mışım, bul-mışım

-miş

giy-miş, üş-miş

-mişem

düş-mişem

-mişim

eyle-mişim

+ n1

$b u+n ı$

+niy

mușțafā+nıy

+nuy

bu+nuy

$+y$

$a t a+y$

-yuz

bağışla-yuz

-yüz

işle-nüz

$-r$

ag̉la-r

- rdi

oḳu-rdı

-rdi

beyze-rdi

-rsem

di-rsem

-sen

i-sen

$+\$ 1$

$\bar{a}^{c} l a ̄+s 1, \operatorname{deva}+s 1$

+ṣ1 
uṢ+Ṣ1

-sin

arıt-sın, çıł-sın

$+\operatorname{Sin}$

ceza+sin

+Sina

ana+sina

$+\operatorname{Sin} 1$

kamı+sını

+ si

cümle+si, çare $+s i$, is $+s i$, pare+si, pāre+si

-sun

ol-sun

-sün

gel-sün, gör-sün, ir-sün

-sünler

vir-sünler

+ten

hastelik+ten

-uban

ol-uban

tum

og̉lan+um

+uma

og̉ul+uma

tun

og̉ul+un

+uy

og̉ul+uy

-up

çağır-up, ḳ1l-up, țut-up

-ur

kal-ur, ḳ1-ur, ol-ur, ur-ur, al-ur, bul-ur tur-ur

-urd1

ol-urd1, çaġır-urdı -ursin

utan-ursin

-üben

düş-üben, üş-üben

+üm

‘ayāl+üm, bülbül+üm, göyül+üm, gül+üm

+ümi

söz+ümi

+ümün

göz+ümün

+üne

ön+üne

+ün

beniz+üy, yüz+üy

-üy

vir-üy

-ür

bil-ür, dönder-ür, eyt-ür, gel-ür, görün-ür, gör-ür, öldür-ür, vir-ür

-ürem

öl-ürem

+ya

dünya+ya, mușțafā+ya, șu+ya, şuhmā+ya

-ya

șuṣa-ya

tye

'alī+ye, elli+ye, gemi+ye

-ye

de-ye, dile-ye

-yelüm

eyle-yelüm, n'eyle-yelüm

-yem

eyle-yem, gizle-yem, söyle-yem

$+\mathrm{y} 1$

șu+yl, şuhmā+yl 
+yım

ara+yım, șarı+yım, șu+yım

-yim

di-yim

-yur

aǵla-yur

-yü

di-yü 


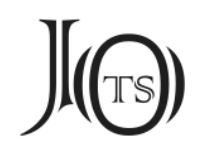

\section{SONUÇ}

Aksaraylı Îsâ, XIV. yüzyılda yaşadığı düşünülen önemli bir meddâh şairdir. Adından anlaşılacağı üzere Aksaray ve Konya çevresinde yaşamıştır. Eserlerinden Arapça ve Farsçaya vakıf olacak derecede iyi bir eğitim aldığı anlaşılmaktadır. Sade ve akıı bir Türkçe ile yazdığı bu gibi hikâyeleri halk meclislerinde icra etmiştir. Eserlerinde işlediği konular dinî ve ahlaki bir çizgidedir. Bu çalışmada Aksaraylı Îsâ'nın Hikâyet-i Şuhmâ adlı eseri ele alınmış ve incelenmiştir.

Çalışmanın giriş kısmından sonra eser konu, içerik, kaynak, özet, kişiler, nüsha özellikleri ve yazar açısından incelenmiştir. Eser, Arap-İslam kaynaklı bir hikâyedir. Hz. Ömer'in Ebu Şahme künyeli oğlu Abdurrahman'ın başından geçen bir olay konu olarak işlenmiştir. İslam tarihi kitaplarında bu konu geçmektedir. Eserin Türk edebiyatı içinde Aksaraylı Îsâ tarafından kurgulanıp öyküleştirildiğini düşünüyoruz. Eser, Eski Anadolu Türkçesi dil özellikleri taşımaktadır. XIV. yüzyıla ait bir metin olduğu düşünülmektedir. Eserde dil ve anlatım yönünden dikkat çeken noktalar üzerine notlar alınmıştır. Eserde Eski Anadolu Türkçesi dönemine aykırı görülen bazı kullanımlar, eserin geç dönemde istinsah edilmesinden kaynaklanmaktadır. Eserdeki bazı kelime ve eklerin kullanımında sonraki dönemlerin dil özellikleri görülmektedir. Halk arasında çok sevilen bu tür eserlerde genellikle daha sonraki dönemlerin yazım özellikleri dile yansımaktadır.

Çalışmanın ana bölümünde eserin Ankara Millî Kütüphane 06 Mil Yz A 6823/2 numarada kayıtlı tek nüshası üzerinden transkripsiyonlu metni, çevirisi ve dizini yapılmıştır. Çevirinin eserin aslına bağlı ve anlaşılır olmasına dikkat edildi. Dizin kısmında genel dizinden başka çekim ekleri dizini, kişi ve yer adları dizini ve Arapça ibareler dizini de yapıldı. Ayrıca eserin 4 varaklık tıpkıbasımı çalışmanın sonuna eklendi.

Aksaraylı Îsâ'ya ait Hikâyet-i Şuhmâ adlı eser ilk kez bu çalışma ile gün ışı̆̆ına çıkmakta ve bilim dünyasına tanıtılmaktadır. XIV. yüzyılda Türkçe eserlerin henüz çok yeterli olmadığı bir ortamda Hikâyet-i şuhmâ gibi eserler o döneme ait önemli dil yadigârlarıdır. $O$ dönemin kültür, dil ve düşünce dünyasının aydınla- 


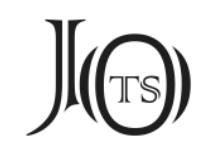

tılmasında bu tür eserler önemli bir işleve sahiptir. Yapmış olduğumuz bu çalışmanın özelde Türk dili ve edebiyatına, genelde bilim dünyasına katkı sağlamasını umarız.

\section{İşaretler}

[ ] = Eksik yazılan ve tamir edilen unsurları gösterir.

\{\}$=$ Mükerrer veya fazla yazıllmış unsurları gösterir.

$?=1$. Şüphe belirtir; 2. Kelimenin kaynağının belirlenemediğini gösterir.

(...) = Düşmüş veya eksik kısımları belirtir.

$<=$ Kelimenin kaynağını gösterir.

>= Kelimenin sonraki şeklini ve değişim aşamalarını gösterir.

+= 1. İsim tabanına gelen ek; 2. Birleşik kelimelerin birleşimini gösterir.

- = Fiil tabanı, fiil tabanına gelen ek.

$\rightarrow=$ bakınız.

$\leftrightarrow$ = karşılaş̧ırınız.

$\sim=$ Kelimenin değişik şekillerini gösterir.

" " = Alıntı ve vurgulanan anlamı gösterir.

\section{Kisaltmalar}

Ar. $=$ Arapça.

bk. = bakınız.

F. $=$ Farsça.

k.a. $=$ kişi adı.

krş. = karşılaştırınız.

$\mathrm{T}_{\mathrm{.}}=$ Türkçe.

$\mathrm{vb} .=\mathrm{ve}$ benzeri.

vd. = ve devamı, ve diğerleri.

y.a. = yer adl. 


\section{$J(\Theta)$}

\section{Kaynakça}

AKALıN, Ş. H. vd. (2011). Türkçe Sözlük, 11. Baskı, Ankara: Türk Dil Kurumu Yayınlar1.

AYVERDİ, İ. (2006). Misalli Büyük Türkçe Sözlük I-III, İstanbul: Kubbealtı Yayınları.

Clauson, Sir G. (1972). An Etymological Dictionary of Pre-Thirteenth Century Turkish, Oxford: Oxford University Press.

ÇAĞBAYIR, Y. (2007). Orhun Yazıtlarından Günümüze Türkiye Türkçesinin Söz Varlı̆̆ı, Ötüken Türkçe Sözlük I-V, İstanbul: Ötüken Yayınları.

Demirci, Ü. Ö. \& Ş. KorKmaz (2008). Şeyyâd Hamza, Yûsuf ve Zelîhâ (Giriş-MetinGünümüz Türkçesine Aktarma-Dizin ve Sözlük-Tıpkıbasım), İstanbul: Kaknüs Yayınları.

DeVellioĞLU, F. (2007). Osmanlıca-Türkçe Ansiklopedik Sözlük, Ankara: Aydın Kitabevi.

Díç̧iN, C. (1991). Mes'ûd Bin Ahmed, Süheyl ü Nev-Bahâr (İnceleme-Metin-Sözlük), Ankara: Türk Dil Kurumu Yayınları.

HiKÂYE (1971). Meydan Larousse, İstanbul, Meydan Yayınları, 5: 850-851.

HiKÂYe (1981). Türk Dili ve Edebiyatı Ansiklopedisi, İstanbul, Dergâh Yayınları, 4: 225-230.

KorKMAZ, Ş. \& T. KorKMAz Bulut (2019). "Eski Edebiyatımızda Hirsızlık Konulu Mensur Bir Hikâye: Hikâyet-i Uğru Abbâs”, Hırsızlık Kitabı, Ed. E. GÜRSOY-NASKALi, Kitabevi Yayınları, İstanbul: 467-478.

KorKMAZ Bulut, T. \& Ş. KORKMAz (2019). “Yûsuf-1 Meddâh'ın Kadı ile Uğru Hikâyesi: Günümüz Türkçesine Çevirisi”, Hırsızlık Kitabı, Ed. E. GÜRSOY-NASKALİ, Kitabevi Yayınlar1, İstanbul: 479-510.

KorkMAZ, [BuLuT] T. (2017). Arzu ile Kanber Hikâyesi [Milli Kütüphane Nüshası 06 Mil Yz A 8618 ve Konya Nüshası 42 Kon 1882/2], (İnceleme-Metin-Çeviri-Dizin ve Tıpk1basım), Marmara Üniversitesi, Türkiyat Araştırmaları Enstitüsü, İstanbul. [Yayımlanmamış Doktora Tezi]

KorkMAZ, Ş. (2012). Eski Anadolu Türkçesine Ait Bir Manzum Hikâye Mecmuası (İnceleme-Metin-Çeviri-Dizin ve Tıpkıbasım), Marmara Üniversitesi, Türkiyat Araştırmaları Enstitüsü, İstanbul. [Yayımlanmamış Doktora Tezi] 


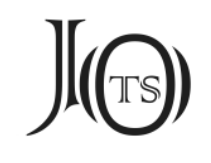

KöKTEKin, K. (2007). Yûsuf-1 Meddâh, Varka ve Gülşah (İnceleme-Metin-Dizin), Ankara: Türk Dil Kurumu Yayınları.

Meninski, Franciscus á Mesgnien (2000). Thesaurus Linguarum Orientalium Turcicae-Arabicae-Persicae, Lexicon Turcico-Arabico-Persicum I-III, Grammatica Turcica IV, Onomasticum V, Index der türkischen Wörter VI, mit einer Einleitung und mit einem türkischen Wortindex von S. STACHOWSKI, sowie einem Vortwort von M. ÖLMEZ. İstanbul: Simurg. İstanbul.

Örnekleriyle Türkçe Sözlük I-IV (1995). Ankara: Millî Eğitim Bakanlı̆̆ı Yayınları.

ÖZKAN, M. (2009). Türk Dilinin Gelişme Alanları ve Eski Anadolu Türkçesi, İstanbul: Filiz Kitabevi.

RÄSÄNEN, M. (1969). Versuch eines etymologischen Wörterbuchs der Türksprachen, Helsinki: Suomalais-Ugrilainen Seura.

SARAÇBAŞI, M. E. (2010). Örnekleriyle Büyük Deyimler Sözlüğü I-II, İstanbul: Yap1 Kredi Yayınları.

Steingass, F. J. (1975). A Comprehensive Persian-English Dictionary, Beirut: Librairie du Liban Publishers.

Şemseddin Sâmi (1985-1986). Temel Türkçe Sözlük I-III (Sadeleştirilmiş ve Genişletilmiş Kâmûs-1 Türkî), İstanbul: Tercüman Gazetesi Yayınları.

TUĞLACI, P. (1971). Okyanus 20. Yüzyıl Ansiklopedik Türkçe Sözlük I-III, İstanbul: Pars Yayınevi.

Tulum, M. (2011). XVII. Yüzyıl Türkçesi ve Söz Varlığı, Ankara: Türk Dil Kurumu Yayınları.

Türkiye'de Halk Ağzından Derleme Sözlüğü I-XII (1993). 2. Baskı, Ankara: Türk Dil Kurumu Yayınları.

XIII. Yüzyıldan Beri Türkiye Türkçesiyle Yazılmış Kitaplardan Toplanan Tanıklarıyla Tarama Sözlüğü I-VIII (1996). 2. Baskı, Ankara: Türk Dil Kurumu Yayınları.

YAĞCI, Ş. (2002). “Klasik Türk Edebiyatı Geleneğinde Hikâye”, Türk Dünyası Araştırmaları, 141: 147-160.

ZENKER, J. T. (1866). Türkisch-Arabisch-Persisches Handwörterbuch, Leipzig.

\section{TIPKIBASIM}




\section{$J(\Theta)$}

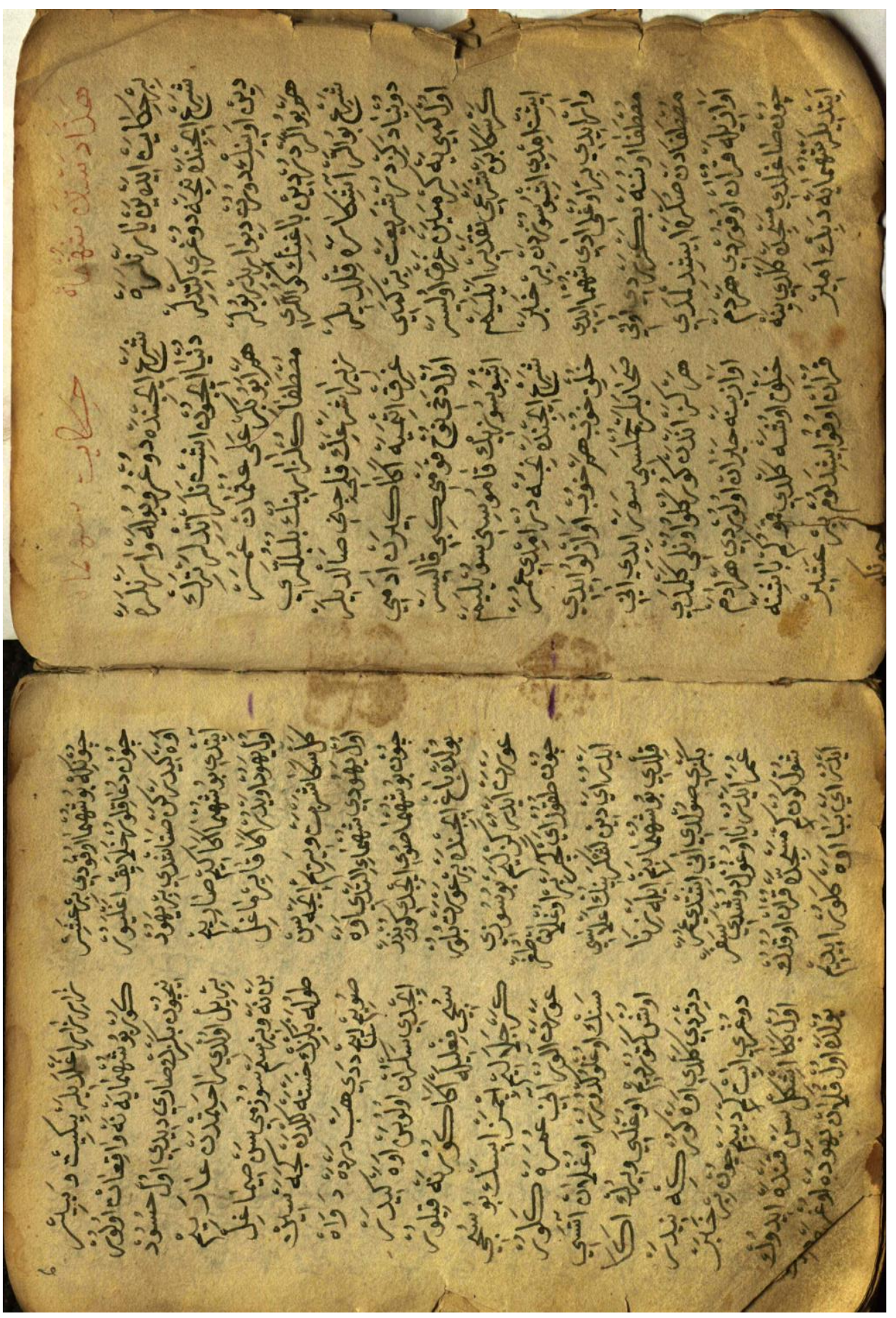

Millî Kütüphane 06 Mil Yz A 6823/2, 5b-6a 


\section{J(৫)}

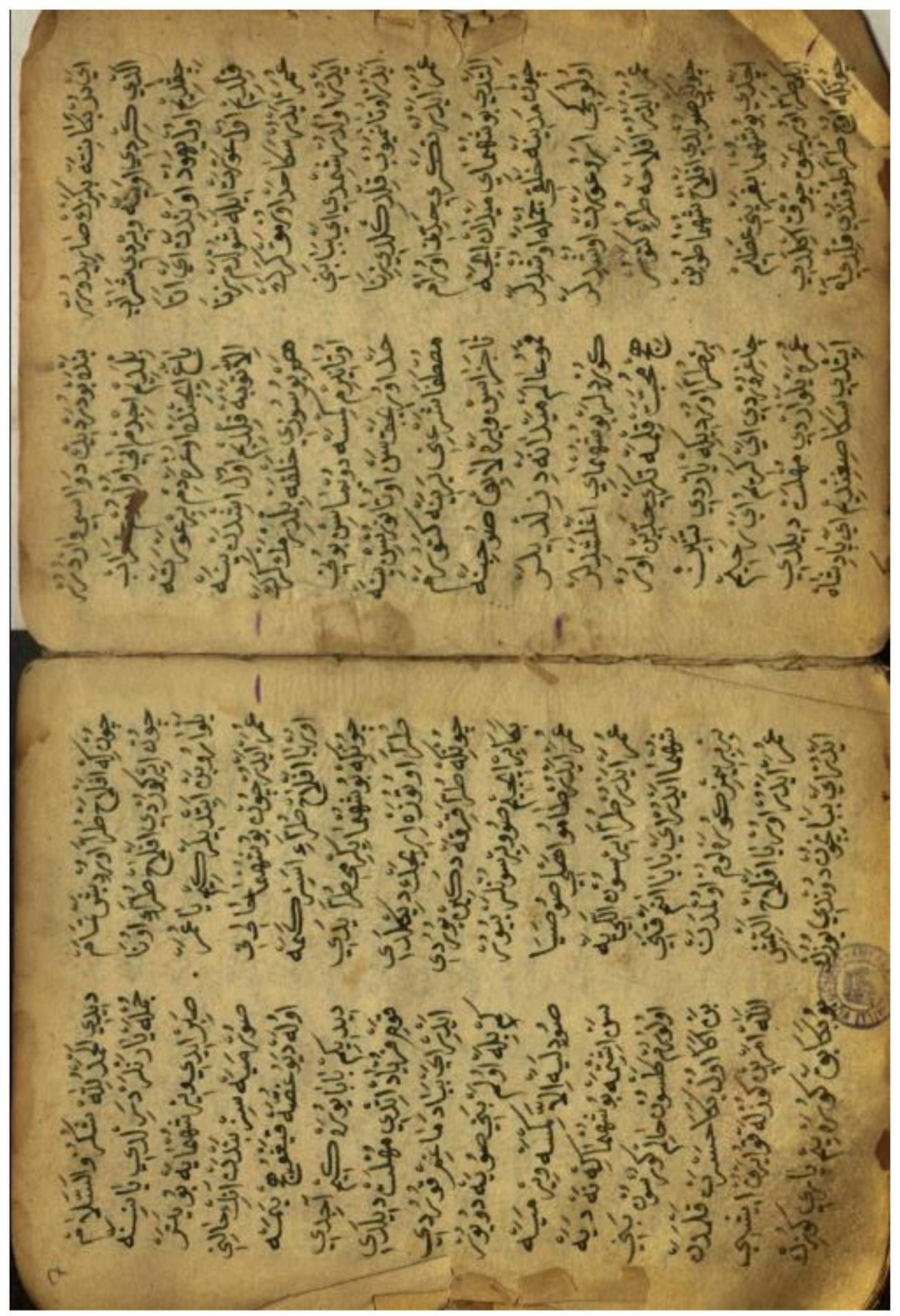

Millî Kütüphane 06 Mil Yz A 6823/2, 6b-7a 


\section{J(৫)}

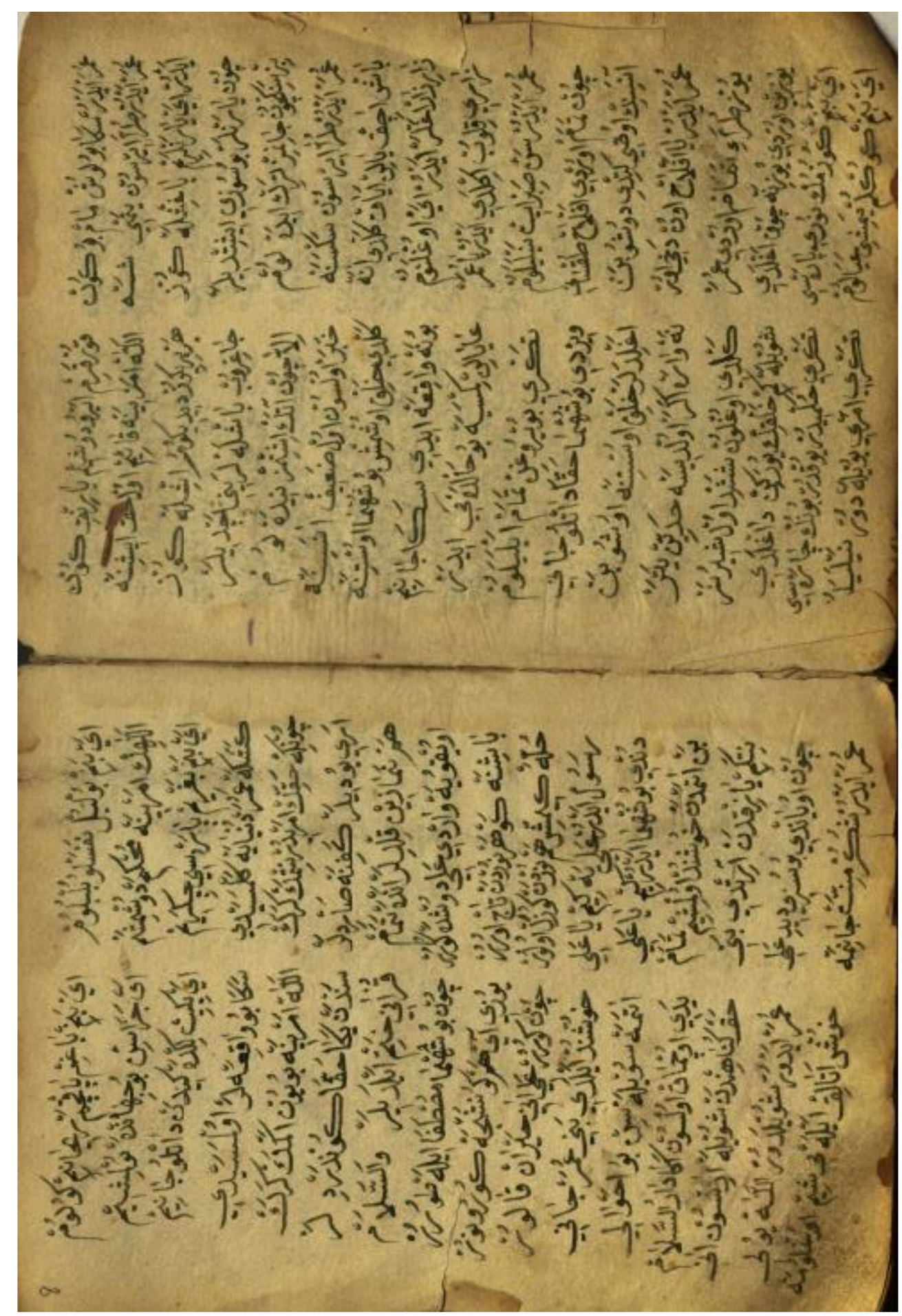

Millî Kütüphane 06 Mil Yz A 6823/2, 7b-8a 


\section{$J($ (O)}

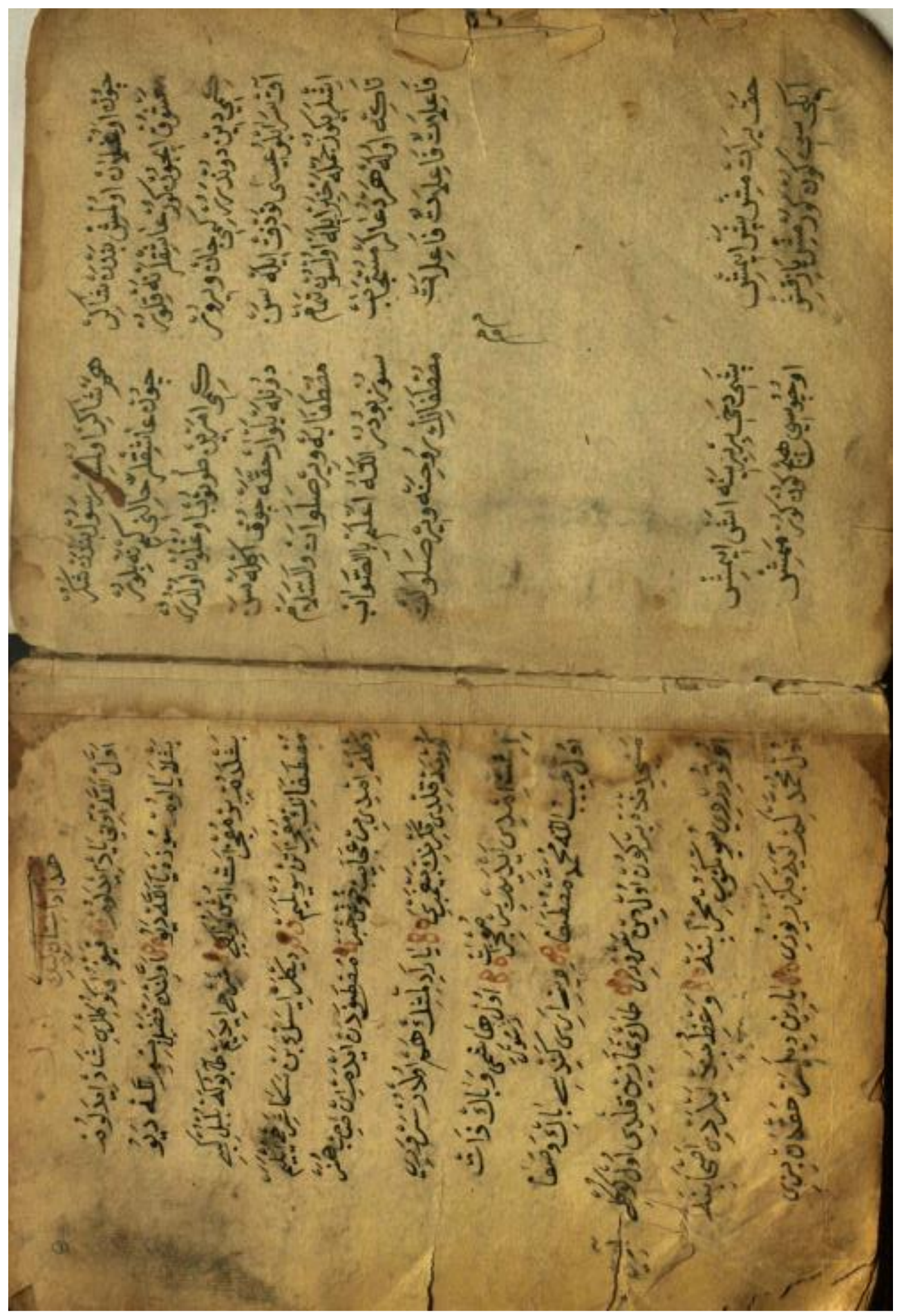

Millî Kütüphane 06 Mil Yz A 6823/2, 8b-9a 